\title{
Análisis del Catecismo de la Iglesia Católica
}

La recepción serena del Catecismo de la Iglesia Católica debe hacer posible que aparezcan con suficiente claridad aquellos aspectos que deben ser tenidos en cuenta, especialmente por parte de quienes tienen que utilizarlo, por el ejercicio de su cargo o ministerio en la Iglesia. Como es natural, no se trata de emprender desde dentro de la propia Iglesia ni un proceso de ostentación de incensarios, acompañados de un coro de adjetivos laudatorios, ni tampoco tener que derribar con la piqueta lo construido (o lo publicado, en este caso). Pero la serenidad tiene que dar de sí lo suficiente como para someter a análisis el texto que acaba de ver la luz pública, sin que nadie se escandalice ni rasgue las vestiduras; y sin que se tenga que producir una declaración de hostilidades entre "partidarios" y "detractores" del aludido catecismo.

La serenidad tiene que ayudar a hacer una lectura reposada, valorativa, exacta, en la que los criterios vertidos puedan ser suficientemente justificados sin que nadie tenga que sentirse ni estimulado ni dolido. Si esto no sucede así, es un claro indicio de que falta la serenidad necesaria para una labor que, por otra parte, estimo que ha de hacerse, para evitar cualquiera de los dos extremos: la aceptación servil, obsequiosa y sin criterio, por una parte; y la rebelión, la ironía o el desprecio desde el prejuicio.

Transcurridos ya dos meses desde la publicación del texto en castellano, habiendo dispuesto de tiempo suficiente para una lectura atenta, reposada y minuciosa, sin las premuras (o peor aún, las improvisaciones) de los primeros momentos, procede llevar a cabo un estudio en profundidad. La intención que dirige mis reflexiones no es otra que la de brindar a otras personas puntos de vista que -naturalmente- pueden o no ser compartidos, pero que en definitiva son los míos, y que me llevan a subrayar una serie de afirmaciones èn unos casos, lagunas y silencios en otros; también me conducen a estimar como aciertos tales o cuales expresiones, frases o párrafos; de la misma manera y con la misma libertad con que puedo decir en otros casos que encuentro fallos y defectos. Sin ánimo de imponer nada, con la voluntad de 
exponer, y con el deseo de que otras personas se fijen donde yo me he fijado, $y$, si les parece oportuno, compartan mis apreciaciones, vean lo que yo he visto, o, en caso contrario, sean capaces de expresar sus opiniones, doy comienzo al presente estudio.

\section{PRELIMINARES INDISPENSABLES}

Antes de entrar en el análisis propiamente dicho del contenido de la obra, no hay más remedio que detenerse obligatoriamente en una serie de aspectos que, como cuestiones introductorias, pero imposibles de soslayar, han de ser examinadas. Dichas cuestiones están planteadas en la Constitución Fidei depositum, que precede al Catecismo, así como en el "Prólogo" de la obra. Ordinariamente son asuntos que se pueden pasar por alto por una cierta precipitación, mientras que a mí me parece que constituyen importantes claves de lectura, que van a proporcionar -o no- el ángulo adecuado para saber situarse con la mayor justeza posible ante un texto que resulta amplio, y por lo mismo, complejo. Además, suele pasar que esos datos preliminares son leídos (cuando lo son), y posteriormente son olvidados, a medida que la lectura o la consulta van derivando hacia un análisis de los contenidos, como si los datos previos carecieran de importancia. Y es justamente todo lo contrario.

\section{La necesidad del Catecismo.}

Juan Pablo II afirma en primera persona que a partir de la clausura del sínodo de 1985 asumió como suyo el deseo allí expresado ${ }^{1}$ juzgando que "responde a una verdadera necesidad de la Iglesia universal y de las Iglesias particulares" 2. Puede observarse el desplazamiento que supone pasar de un deseo a una necesidad. La carga que se da a la correspondiente afirmación no es ni mucho menos la misma, y hasta el observador menos avispado percibe que cuando se expresa un deseo no se está en la misma situación que

1 "Muchos han expresado el deseo de que se redacte un catecismo o compendio de toda la doctrina católica en lo que se refiere tanto a la fe como a la moral, para que sea un punto de referencia para los catecismos o compendios que son preparados en las diversas regiones. La presentación de la doctrina debe ser bíblica y litúrgica. Se debe tratar de una sana doctrina adaptada a la vida actual de los cristianos" Relatio Finalis, II, B, 4)

2 Fidei depositum, 1 (pg. 8 de la versión castellana). Citaré únicamente las páginas en estos aspectos preliminares, ya que no siempre existe una distribución por números o párrafos que permita una fácil localización. En Fidei depositum, 1 (pg. 9), aparece otra expresión que podría rebajar el imperativo que comporta la palabra necesidad, si no fuera por el empleo de un superlativo que vuelve a resaltar lo que antes había aminorado el substantivo, al calificar al catecismo como una "contribución importantísima para la obra de renovación de la vida eclesial". 
cuando se formula una necesidad ${ }^{3}$. Ciertamente, el Papa es muy libre de estimar si se trata de una verdadera necesidad el proceder a la publicación de una obra de este tipo.

A mí, desde los datos de que dispongo, me parece que no había tal necesidad, en términos generales. Para una gran parte, para una parte sana y saneada de la Iglesia, no había tal necesidad; y ello porque disponía de recursos sucifientes como para poder echar mano de todos aquellos datos indispensables para formular y explicar adecuadamente su fe; e incluso tenía la libertad suficiente como para pedir ayuda a otras iglesias locales, en demanda fraternal de comunicación de bienes en la misma fe ${ }^{4}$. Es posible, como se ha dicho en algunos medios de comunicación, que ciertos sectores de la Iglesia, especialmente los procedentes del tercer mundo, percibían con mayor claridad los beneficios que podría reportarles la elaboración de un Catecismo. Si esto es así, habría que hablar, para ser exactos, que podría llegar a ser necesaria la publicación de un Catecismo en algunas Iglesias particulares; pero de ahí no infiero que tal necesidad haya de hacerse extensiva a la totalidad de la Iglesia 5 .

Estamos en el terreno de lo opinable. Y precisamente por ello, opino. Y lo hago ratificándome en que, desde mi estimación, tal necesidad no era tal. La gama de matices es muy amplia, pues podría haberse hablado de un deseo, una oportunidad, una conveniencia, una utilidad,... Hablar de necesidad lleva a ponerse en una situación poco menos que insostenible, desde la que se lanza una llamada de socorro, un "S.O.S" desesperado. Creo que no se estaba, ni se está actualmente en la Iglesia, en semejante trance; y me apoyo en los muchos esfuerzos catequéticos, muy sanos y válidos en numerosas ocasiones, que demostraban y demuestran una vitalidad nada despreciable; junto a esos esfuerzos, había otros intentos fracasados y corregibles. Pero, sinceramente, creo que eran los menos.

3 Hay también otro desplazamiento, de no pequeño interés, en el sentido de que el texto de la Relatio finalis hablaba de que muchos (o, según otra versión, de modo muy común...) habían expresado tal deseo, en tanto Jan Schotte, secretario general del Sínodo, al presentar públicamente la Relatio finalis utilizó la expresión de la "necesidad vivida por todos los obispos".

4 Es precisamente lo que ha sucedido con el Katholischer Erwachsenenkatechismus, o catecismo alemán para adultos, inteligentemente adoptado para su territorio por la Conferencia Episcopal Austríaca, el 3 de julio de 1985, en un servicio de préstamo de elementos de educación de la fe que estiman válidos y que son procedentes de otras iglesias locales.

5 Sin embargo, M. DEL CAMPO, ¿Era necesario un catecismo universal?, en "Vida Nueva" n 1897, 17-19, aboga por la necesidad absoluta, sin ningún tipo de matizaciones. Puede observarse el hecho de que refrende la afirmación absoluta de la necesidad del Catecismo, con la adición del adjetivo "universal", adjetivo que debería ser empleado con mucha cautela. 
2. Texto de referencia seguro.

En la constitución Fidei depositum se afirma (n. 1, pg 8; n. 4, pg. 11) que el catecismo constituye un texto de referencia seguro para la presentación de la fe cristiana.

El propio Juan Pablo II hace además una afirmación citando anteriores palabras suyas, según las cuales, "el Vaticano II ha sido siempre... el punto constante de referencia de toda mi acción pastoral" (n. 1, pg. 8). Es perfectamente normal que pueda haber más de un punto o texto de referencia para guiar la actuación personal de cualquier cristiano. Pero no es éste el sentido de las afirmaciones, sino que lo que parece establecerse es un paralelismo entre el Concilio Vaticano II y el Catecismo, del que se afirma rotundamente que es "texto de referencia para una catequesis renovada". Me parece peligroso establecer un tan sutil paralelismo. La más rancia tradición eclesial ha distinguido entre las solemnes afirmaciones magistrales de un concilio ecuménico, y las afirmaciones de un catecismo, que no es documento conciliar, ni tiene por qué verse aureolado de ese tinte.

Aclarado ese punto, habrá que afirmar que si constituye un texto de referencia, lo será desde dos perspectivas complementarias: $1^{\mathrm{a}}$ ) porque intencionalmente lo hayan pretendido sus mentores (sínodo, comisión cardenalicia, comité de redacción, y el mismo Juan Pablo II al aprobarlo); y 2a) porque realmente clarifica datos sobre la fe, y orienta tanto en los aspectos del conocimiento de la fe cristiana, como en la práctica de la misma vida cristiana. Pero ocurre que, si resulta evidente que la primera condición de la intencionalidad se cumple plenamente, según se deduce de las mismas manifestaciones que he reproducido, no se puede decir lo mismo respecto a la segunda condición en todas las afirmaciones que el Catecismo incorpora, ya que son muchos los aspectos en los que el Catecismo no resulta suficientemente clarificador, o incorpora insuficientemente y con timidez logros conseguidos, o hace suyas afirmaciones más que discutibles, que comprometen muy seriamente el pretendido papel de texto de referencia. Es verdad que esto no se puede afirmar de los grandes y substanciales quicios de la fe cristiana; pero no es menos verdad que sí se puede afirmar de otras muchísimas afirmaciones "secundarias", derivadas, en las que no se compromete para nada la ortodoxia, pero en las cuales se presentan puntos de vista o criterios enormemente discutibles. Decir que se pretende que el Catecismo es texto de referencia podría ser legítimo, si no hubiera descendido a tal cúmulo de äfirmaciones intrascendentes para la genuina fe, en las cuales de ninguna manera se puede compartir el carácter normativo de que se quiere dotar al texto. 
Además, conviene ahondar aún en el carácter de texto de referencia que se pretende para el Catecismo. Me causa una profunda pena que, mientras no existe inconveniente en otorgar al Catecismo el carácter de texto de referencia, se haga omisión expresa de lo que es verdaderamente referencial para la Iglesia, como es la misma Palabra de Dios: por increíble que parezca, entre la multiplicidad de textos conciliares reproducidos en el Catecismo, no aparece el texto de Dei Verbum, 21: "La Iglesia ha considerado siempre como suprema norma de su fe la Escritura unida a la Tradición, ya que, inspirada por Dios y escrita de una vez para siempre, nos transmite inmutablemente la palabra del mismo Dios" " 6 . Se puede seguir reclamando para esta obra la condición de texto referencial, cuando omite precisamente la referencia a la que constituye "suprema norma de su fe"? Estamos ante una grave inflexión, ya que la norma referida (Catecismo) eclipsa a la norma referente (Palabra de Dios): la luna quiere emitir su luz al sol para que sea éste quien la refleje. Y esto no puede ser. Ni siquiera se puede aducir en descargo del Catecismo que cumple realmente su función ya que cita con profusión textos bíblicos de forma habitual; si bien esto es cierto, en ningún momento se puede pretender un golpe de estado mediante la substitución de una norma por otra.

Otro aspecto hay que considerar aún, que sirve de puente para empalmar la cuestión de texto referencial con la anterior de la necesidad del Catecismo. Formulada a modo de pregunta, sería así: Con anterioridad a la aparición del Catecismo de la Iglesia Católica, ¿carecía la Iglesia de textos de referencia? Sinceramente creo que hay que responder que no, por fortuna. Es decir, la Iglesia, en su conjunto se encuentra en un momento en que dispone de variadas reflexiones referenciales sobre su fe, lo bastante amplias, lo bastante razonadas, lo bastante equilibradas, como para poder asegurar, sin miedo a equivocaciones que existían -y siguen existiendo- una serie de textos referenciales enormemente útiles ${ }^{7}$. No deja de ser cierto que se han

6 En los n. 104, 131 y 141 aparecen otras frases de este mismo párrafo de Dei Verbum, 21, pero el pasaje substancial y más importante ha quedado excluido de las páginas del Catecismo.

7 Por señalar algunos, en el terreno de la catequesis, sugiero los siguientes: Nuevo catecismo para adultos. Versión íntegra del Catecismo Holandés, Barcelona, Herder, 1969, que después de las oportunas correcciones continúa siendo una guía muy válida; CONFERENCIA EPISCOPAL ESPAÑola, Con vosotros está, Madrid, Secretariado Nacional de Catequesis, 1976', el más valioso logro catequético español, que en nada ha perdido actualidad y claridad, pese a que haya sido retirado de la circulación; J. FEINER-L.VISCHER, Nuevo libro de la fe cristiana, Barcelona, Herder, 1977, excelente trabajo, que destaca principalmente en la dimensión ecuménica al presentar la fe, desde distintos enfoques cristianos; G. J. DYER y otros, Catecismo de la doctrina católica, Barcelona, Herder, 1979, con el propósito de responder a una presentación actualizada de la fe, saliendo al paso de interrogantes suscitados por la cultura o el entorno actuales; $R$. BECKER-M.L. FISCHER-G. FUCHS, Exposición de la fe cristiana. Catecismo católico para el estu- 
publicado algunas obras catequéticas que albergaban serias dudas sobre su oportunidad o sobre su ortodoxia. Estas, sin embargo, no constituían la mayoría.Y nadie puede decir que viviéramos un momento de penuria catequética ni de falta de esfuerzos. Otra cosa distinta es que exista una diferencia entre los catecismos escritos y la vivencia de la fe del pueblo cristiano; pero eso mismo puede seguir produciéndose con la publicación de este nuevo Catecismo. Y si había referencias anteriores, nada impide que las siga habiendo después de la publicación de la obra comentada, que pueden -y deben intentarlo-superar los fallos de que adolece este Catecismo.

Quiero cerrar este apartado a propósito de la declaración de texto de referencia, con una calificación aneja, ya que son dos la ocasiones en que se repite la misma idea: en Fidei depositum, 4 (pg. 10 y pg. 11) al afirmar que es "norma segura" y "texto de referencia seguro". La afirmación, en principio, es impecable. Cualquier grupo humano que busca definirse, sea o no religioso, tiende a presentar normas seguras; y en la oferta de normas equívocas, dudosas o ambiguas existe una tendencia suicida irreprimible. Quizá sea éste el momento oportuno para recordar que la exhortación Catechesi tradendae, 60 reclamaba para la catequesis la presentación de las "certezas sencillas, pero sólidas" de la fe.

Ahora bien, en el Catecismo de la Iglesia Católica se encuentran, por igual, y en ocasiones sin diferenciación (de manera que un lector no avezado encuentra serias dificultades para distinguirlas), afirmaciones que constituyen certezas en la fe cristiana, junto a otras que no lo son tanto, ni mucho menos (cuestiones "abiertas", aspectos completamente secundarios o marginales, afirmaciones absolutamente innecesarias,...). Por ello hay que concluir que la norma segura en la intención se trastoca en norma confusa en la práctica; con ello el principio resulta irreprochable, pero no así su puesta en práctica en las páginas impresas del Catecismo, lo que empaña el papel que se le ha asignado.

Siguiendo en cierto modo pautas que se tuvieron en cuenta en la redacción del Catechismus romanus, de Trento, se han tratado de omitir las cues-

dio personal y la enseñanza, Salamanca, Sígueme, 1983, relativamente breve, pero muy atinado en sus exposiciones; Conferencia Episcopal Alemana, Catecismo católico para adultos. La fe de la Iglesia, Madrid, BAC, 1988, exposición amplia y densa, además de clara y luminosa de las cuestiones principalmente dogmáticas; CONFERENCIA EPISCOPAL FRANCESA, Catecismo para adultos. La Alianza de Dios con los hombres, Bilbao, Desclée, 1993. Y además, se pueden incluir, aun contando con que sus enfoques o planteamientos pedagógicos resultan más discutibles en una serie de puntos: Los OBISPos De BelgiCA, Libro de la fe, Bilbao, Desclée, 1990; ConfERENCIA EPISCOPAl EsPañola, Esta es nuestra fe. Esta es la fe de la Iglesia, Madrid, Edice, $1986^{1}$.

A la vista de todos estos datos, referidos tan sólo a Europa, y algunos otros que se podrían ampliar al ensanchar el horizonte, creo que está suficientemente justificado que sí que había -para quien quería consultarlos- suficientes puntos referenciales para conocer, explicar y profundizar en la fe. 
tiones "de escuela", los puntos de vista que no estaban suficientemente contrastados (lo cual introduce la cuestión de cuándo una afirmación de fe está "suficientemente contrastada"). Pero la diferencia entre los tiempos del XVI y los de finales del XX, eran las agrias disputas entre católicos y luteranos, por una parte, $y$, por otra, las rencillas interescolares que se venían arrastrando desde el medievo, en tanto que en nuestros días lo que se produce es un replanteamiento de la fe, para ajustarlo a un devenir del pensamiento, sin esas rencillas internas. Hoy nadie -nadie serio- se presitúa en una determinada posición como consecuencia de la familia $u$ orden religiosa a la que pertenece. Y los criterios son aceptados o rechazados en función de la calidad intrínseca de las razones que los sustentan. De ahí que se ha producido una merma destacable, porque al querer incorporar al Catecismo aquello que parecían a sus redactores datos seguros de la fe, se ha dejado de lado una notabilísima parte de la reciente y contrastada reflexión bíblica, teológica, antropológica o moral, con la pérdida de actualización que ello comporta. ¿Cuántos años más tendrán que pasar para que algunas de esas reflexiones puedan ser estimadas como seguras? La seguridad, en este caso, ha supuesto sacrificar la actualización. Y así, nos encontramos un Catecismo seguro, pero viejo. $Y$ en esas condiciones, ¿cómo se puede "mirar sin miedo hacia el futuro" (según palabras de Juan XXIII, recogidas en Fidei depositum, 1, pg. 8)?

\section{Carácter instrumental del Catecismo.}

Gracias a Dios, la constitución Fidei depositum, 4 recoge abiertamente que el Catecismo "es un instrumento válido y autorizado" (pg. 10) y constituye "un servicio que el sucesor de Pedro quiere prestar a la Santa Iglesia Católica" (pg. 11). Tales afirmaciones, fechadas el 11 de octubre de 1992, vienen a poner las cosas en su sitio respecto a las declaraciones que con ocasión de la aprobación del Catecismo, emitió el cardenal Joseph Ratzinger, en las que afirmaba que "no se trata de 'un' catecismo, sino de 'el' catecismo", así como que "el nuevo catecismo 'obliga' a todos porque se trata de un mandato del Papa" ${ }^{8}$. El Papa dice que es un instrumento, válido y autorizado, lo que en modo alguno excluye la utilización de otros instrumentos, e incluso posibilita la creatividad para que otros instrumentos, anteriores o posteriores a la redacción del presente, acierten a presentar la fe de la mejor forma posible. Esa categoría instrumental hace que haya que dar prioridad al catequista por encima del catecismo. Mucho más importante que el catecismo lo es el catequista; mucho más importante que un libro, lo es un testi-

8 "Vida Nueva, n 1.849, 4 de julio de 1992, 37. 
go de la fe. El libro puede resolver dudas, aclarar conceptos, ofrecer respuestas...; pero el testigo de la fe, da testimonio directo "de lo que ha visto y oído". Todos hemos necesitado libros que nos ayudaran, pero hemos necesitado más aún, testigos que nos convencieran y que nos movieran a creer. Y el catequista que no sabe hacer otra cosa más que repetir con insistencia lo que encuentra escrito en un libro, mal catequista es.

Además, el sencillo y modesto ofrecimiento del Papa al presentarlo como un servicio a la Iglesia, en perfecta sintonía con Lumen gentium, 27, dista mucho de la rotunda afirmación de Ratzinger. A quien, por otro lado, se podría argumentar con las palabras del propio Catecismo cuando afirma que "Cristo invitó a la fe y a la conversión. El no forzó a nadie jamás" (n. 160). Si Jesús de Nazaret no forzó, ¿cómo es posible exigir como obligatorio el empleo de un instrumento que se brinda como servicio eclesial?

Precisamente por eso me da miedo una especie de irresponsable echar las campanas al vuelo con ocasión de la publicación de esta obra, en un clima de falsa euforia eclesial, como si con ello estuvieran resueltos todos los asuntos pendientes, o se tratara de una tabla indefectible de salvación frente a una crisis universal de la Iglesia o de la sociedad. En ese clima hay que inscribir tanto algunas declaraciones altisonantes que justificaban una tirada excepcional (y no querían ver los muchos ejemplares vendidos por pura concesión a la novedad, destinados a cubrirse de polvo por muchos años), así como -y acaso es bastante más serio- la tendencia a fijarlo como único texto posible, de lo cual, por desgracia, ya tenemos una muestra temprana ${ }^{9}$.

Yo me inclino, más bien, por una recepción serena, sin alharacas ni complejos, en la sana valoración que proporciona un sensato uso de lo que es un instrumento para la catequesis, pero no es el único útil posible; y en algunos casos, no hay más remedio que reconocer que puede resultar contraproducente por su dificultad intrínseca. De ahí que la batalla no tenga que situarse en si se usa o no este instrumento, sino en si se presenta o no adecuada y legítimamente la fe cristiana. $\mathrm{Y}$ en ese caso habrá que recibir con

9 "El nuevo catecismo, texto catequético en las parroquias de Cuenca", en "Vida Nueva", n 1.879, 30 de enero de 1993, 11.

La idea de texto "único" venía incubándose desde tiempo atrás. La Comisión Editorial del Catecismo, al percatarse de lo peligroso de la afirmación trató de eliminarla sistemáticamente de toda manifestación pública, así como el otro adjetivo, casi equivalente de "universal". Pese a todo el cuidado puesto, y pese a todas las declaraciones de principios en el sentido de que no existía voluntad unificadora, la fatídica palabra se ha deslizado: "Todos aquellos que han enviado su juicio estuvieron de acuerdo, casi unánimemente, en considerar como actual y necesario, a la vez que urgente, un texto catequístico único para toda la Iglesia Católica" (Comision EdiTorial del Catecismo de la Iglesia Catolica, Dossier informativo, Ciudad del Vaticano, Librería Editrice Vaticana, 1992, 27). 
gozo (que no es lo mismo que con cohetería) a todo instrumento que preste un servicio útil.

\section{El asunto de los destinatarios.}

Se trata, en realidad, de una ceremonia de la confusión, en la que cada una de las autorizadas expresiones oficiales ha dicho cosas distintas, que no contribuyen más que a despistar. De ahí que haya sido enteramente lógica una manifestación de la Asociación Española de Catequetas, que recoge el reto, al manifestar que existe "confusión en cuanto a los destinatarios".

Aparecen tres expresiones no completamente coincidentes de los destinatarios del Catecismo. En primer lugar, el Dossier informativo, publicado por la Comisión editora, que señala tres destinatarios diversos: "Son destinatarios del Catecismo de la Iglesia Católica, sobre todo y ante todo los Obispos [1] en cuanto doctores de la Fe; luego los redactores de catecismos [2] y, a través de ellos, todo el Pueblo de Dios [3]" ${ }^{10}$. En la constitución Fidei depositum, 4 (pg. 11) aparecen no tres, sino seis destinatarios diversos: "Es un servicio que el sucesor de Pedro quiere prestar a la Santa Iglesia Católica [1] (...) pido, por tanto, a los pastores de la Iglesia y a los fieles que reciban este Catecismo... este Catecismo les es dado [a los obispos] para que les sirva de texto de referencia seguro y auténtico para la enseñanza de la doctrina católica, y muy particularmente para la composición de los catecismos locales [2-3]. Se ofrece también a todos aquellos fieles que deseen conocer mejor las riquezas insondables de la salvación [4]. Quiere proporcionar un punto de apoyo a los esfuerzos ecuménicos [5]... es finalmente ofrecido a todo hombre que nos pida razón de la esperanza [6]". Todavía hay que añadir nuevos datos a los ya aparecidos, puesto que entrando en la misma obra, el prólogo vuelve a abordar la cuestión, y a este propósito aparece en esta ocasión cuatro destinatarios, que no coinciden siempre con los ya enumerados: "El presente catecismo está destinado... en primer lugar a los obispos, en cuanto doctores de la fe y pastores de la Iglesia [1]... a través de los obispos, se dirige a los redactores de catecismos [2], a los sacerdotes [3] y a los catequistas [4]" (n. 12).

Es decir, que en el conjunto de estas afirmaciones, se ha ido ampliando el círculo de destinatarios, en ocasiones con frases genéricas o poco precisas, lo que propicia más la confusión que la claridad, ya que en total llegamos a encontrar hasta ocho destinatarios diversos:

10 Comision Edtorial del Catecismo de la Iglesia Catolica, Dossier informativo, Ciudad del Vaticano, Libreria Editrice Vaticana, 1992, 23. En la pg. 29, a propósito del tercer destinatario, el Pueblo de Dios, emplea otra expresión similar: "es dirigido a toda la Iglesia". 
1) la Iglesia en su conjunto

2) los obispos, en cuanto doctores de la fe

3) los redactores de materiales catequéticos

4) los cristianos cultos con ánimo de profundizar en su fe

5) los protagonistas del diálogo ecuménico (desde la vertiente católica)

6) los sacerdotes, con independencia de la ocupación que desempeñen

7) los catequistas (de los que no se precisa si todos o sólo algunos)

8) todo hombre (se supone que no católico) que quiera conocer autorizadamente en qué consiste la fe católica.

La verdad es que el refrán que afirma que "quien mucho abarca poco aprieta" vuelve a comprobarse, porque aunque sea cierto que no haya que establecer unos destinatarios tan perfectamente delimitados que no admitan excepciones, lo que no resulta válido es que tan heterogéneos colectivos de personas pueden ser por igual destinatarios de la obra. Por otra parte, la lectura reposada lleva al firme convencimiento de que, por sentido común, muchos de los hipotéticos destinatarios, luego no son lectores natos de las afirmaciones contenidas en la obra. No tengo más remedio que recordar, con sincera lamentación, que no es ésta la primera vez que se ha producido una confusión orquestada, similar a la presente: con ocasión de la publicación de Esta es nuestra fe. Esta es la fe de la Iglesia, de la Conferencia Episcopal Española, ya ocurrió lo propio ${ }^{11}$. ¿Cómo es posible reincidir en el mismo tropiezo? Es evidente que el Catecismo no se trata de un documento reservado y secreto. Pero hay mucha diferencia entre señalar unos destinatarios naturales (obispos y redactores de materiales catequéticos), por medio de los cuales es posible ir trasvasando los contenidos de la fe cristiana -como ya se estaba haciendo- al Pueblo de Dios en sus diversas situaciones. Lo que ocurre es que de haber sido consecuentes con este criterio, que parece el más sensato a juzgar por el contenido y el estilo del Catecis$m o$, se tendrían que haber evitado las difusiones masivas y las tiradas espectaculares. Y acaso quienes tenían que tomar esta decisión no estaban dispuestos a pagar semejante precio, sacrificando la "popularidad".

\section{El esquema del Catecismo.}

He percibido en diferentes comentarios aparecidos, una voluntad más o menos explícita de loa al Catecismo, en razón del esquema que incorpora.

11 L. REsines, "Esta es nuestra fe", pero... ¿ésta es nuestra fe?. Anotaciones al Tercer Catecismo de la Comunidad cristiana, en "Estudio Agustiniano" 23 (1988) 403-410. En esa obra, a propósito de los destinatarios, aparecían: 1) los cristianos más jóvenes; 2) la infancia adulta y la niñez; 3) las familias cristianas; 4) los catequistas; 5) los responsables de catequesis; 6) los fieles de toda edad ("dei fedeli di ogni età"); 7) los adultos. 
Creo que una cosa es que disponga de una estructura válida y pensada (hubiera sido mucho peor que no la hubiera tenido), y otra cosa completamente distinta es que ello lleve a entonar panegíricos. Lo menos que se puede pedir a una obra es que responda a un esquema lógico. Y el Catecismo de la Iglesia Católica ciertamente dispone de él. De ahí que sea bueno no poner tantos acentos encomiásticos en un hecho que debería ser conceptuado como "normal". Otra cosa diferente es proceder a una reflexión pausada sobre tal esquema cuando se trata, por ejemplo en un centro teológico o catequético de realizar un análisis de la obra en cuestión.

Por otra parte, no había que hacer excesivas manifestaciones, cuando en absoluto se trata de ninguna novedad, en el terreno de la catequética. Este Catecismo se limita a servirse del esquema del Catechismus romanus, brotado del concilio de Trento. Quizá, como consecuencia de la admiración excesiva que manifestó en su día Joseph Ratzinger ${ }^{12}$. Por otra parte, tampoco en este caso se trataba de ninguna originalidad, puesto que son numerosas las referencias a esquemas cuatrimembres en la presentación de la fe, unos anteriores a Trento (los hay que le preceden en bastantes años), mientras que otros le siguen o son contemporáneos. Enumerar todos ellos sería tarea excesivamente prolija ${ }^{13}$. Por ello no ha de ser un "mérito" que tenga que ser enaltecido más allá de la simple presentación con vistas a que el texto sea mejor percibido. Pero conviene no olvidar que la calidad de un catecismo determinado no proviene de que su esquema interno sea bueno o malo, sino de la recta presentación, de la adecuada acomodación a los destinatarios, de la fundamentación de sus afirmaciones, etc... Es decir, el esquema no pasa de ser uno más de los aspectos que han de ser tenidos en cuenta.

Sin embargo, hay un dato que no puede pasar desapercibido: se trata de que en el esquema previo enviado a consulta, el esquema que articulaba el contenido no era cuatrimembre, sino trimembre: primera parte: la profesión de la fe cristiana (el credo o "la fe profesada"); segunda parte: la celebración del misterio cristiano (los sacramentos o "la fe celebrada"); y tercera parte: la vida en Cristo (los mandamientos o "la fe vivida"); a ello se añadía un "epílogo", de tan sólo 20 páginas, sobre la oración del Señor, padre nuestro.

12 Conferencias pronunciadas en Notre Dame de Fourvière (Lyon) el 15 de enero de 1983, y en Notre Dame de Paris el 16 de enero de 1983, en el transcurso de las cuales se refiere al catecismo de Trento en tonos admirativos no menos de doce veces; su propuesta, entonces, era pura y simplemente la vuelta al catecismo de Trento, como el medio de salvaguardar la catequesis de las nefastas consecuencias de la incorporación de los datos de la experiencia humana.

13 Puede consultarse, aunque no resulte exhaustivo, S. Misser, La división del nuevo catecismo nacional (Bajo el punto de vista teológico-pastoral e histórico), en "Boletín de Orientación Catequística", II época, nº 14-15, sep-dic. 1962, 18-26. 
No pocas de las anotaciones y correciones apuntaban al papel desmerecedor que se otorgaba en el conjunto del esquema a algo tan capital para el cristiano como era la oración. Consecuencia de ello es que se procedió a una revisión de este "epílogo" para transformarlo en "cuarta parte". Cualquier lector que esté en conocimiento de este dato percibe claramente que la transformación no ha producido un resultado bueno, sino que por medio de la acumulación de propuestas, citas y reflexiones se ha ido engrosando un epílogo magro para que forme la cuarta parte; pero incluso he encontrado algunos lectores que, desconocedores de la génesis de esta cuarta parte, percibían la poca fluidez, el des-orden, y la carencia de "tono", de estilo, en el tratado sobre la oración cristiana.

\section{Las indicaciones prácticas.}

Los $n^{\circ} 18-22$ del Catecismo contienen una serie de indicaciones prácticas destinadas a orientar al lector en el manejo de la obra. Por desgracia, tales indicaciones dejan mucho que desear.

Se empieza afirmando que se trata de una exposición orgánica de la fe, y que, en consecuencia, hay que leerlo como una unidad. A continuación se pasa a afirmar que numerosas citas bíblicas están únicamente apuntadas, para que se pueda proceder a su consulta. Se remite al final de la obra, para el empleo de los índices. Pero cuando uno consulta el "Indice de textos", se encuentra con la sorpresa (no aclarada en parte alguna) de que unas referencias de la multitud de documentos aportados van acompañadas de un asterisco, mientras que otras carecen de él ¿La diferencia? Las citas que tienen asterisco señalan el lugar en que únicamente se hace referencia al texto, mientras que las que van sin asterisco son aquellas en que la cita del texto es expresa y literal. Tanto no hubiera costado introducir esta aclaración en las indicaciones prácticas.

Además, tampoco aparece en el lugar de las indicaciones prácticas una nota, que luego consta en el n. 27, a propósito de los números marginales, que abordan otras cuestiones paralelas, o con afinidad en los temas. Parece oportuno que tal nota hubiera integrado el capítulo de las indicaciones prácticas.

Pero acaso lo apuntado hasta ahora sea lo menos importante. Nada se dice del empleo de la letra de cuerpo grande o normal, con relación a la letra pequeña, de la que se hace una indicación en el n' 20: "Cuando, en ciertos pasajes, se emplea letra pequeña, con ello se indica que se trata de puntualizaciones de tipo histórico, apologético o de exposiciones doctrinales complementarias". Esto es sistemáticamente incumplido. En ocasiones tiene la misma entidad el texto que aparece en el cuerpo de la obra que el que figura 
como "complementario" en letra pequeña. Y en no pocas ocasiones es precisamente al revés, siendo fundamental, clave y punto de partida lo que figura en letra pequeña, de lo cual constituye una explicación lo que aparece en letra grande. Y ello da pena, además de que se ha producido una inaceptable inversión de términos, al relegar a la categoría de secundario lo que resulta principal. Habrá ocasión de volver sobre este punto más adelante.

También se dice ( $\left.n^{\circ} 21\right)$ que las citas en letra pequeña tratan de enriquecer la exposición doctrinal, escogidas "con miras a un uso directamente catequético". Esto es más que discutible. Dejando aparte la cuestión de que, materialmente, las citas mismas se han hecho siguiendo unos criterios muy poco habituales, el uso catequético directo reviste no pocos problemas. Uno de ellos lo constituye el mismo tono, difícil, de la mayor parte de los documentos citados; otro, no despreciable, es que las citas han sido sacadas de contexto, y en alguna ocasión, alteradas, o mal referenciadas; y otro, que constituye un obstáculo insuperable, es que en ocasiones aparecen frases latinas, de las cuales algunas -pero no todas- van acompañadas de la traducción correspondiente. Si se hace la versión completa del texto, ¿qué justificación hay para dejar algunas frases o expresiones bilingües, e incluso para dejar algunas en latín? ¿Por qué no se traduce todo, sin más? Porque si lo que se pretende es una mayor fidelidad al original, entonces no habría que traducir ninguna.

Sobre esta misma cuestión, otro asunto de notable entidad es que en ocasiones el texto que aparece en letra grande es mínimo, y simplemente introductorio para el que figura a continuación en letra pequeña; con más frecuencia de lo que podría parecer a primera vista, el texto en letra grande y en letra pequeña se exigen y reclaman mutuamente, con lo cual no se aprecia el carácter "complementario" y "enriquecedor" que se le quiere dar. Ambos van inevitablemente unidos. Si de verdad tuvieran únicamente el pretendido carácter complementario, se podría prescindir de tales aclaraciones, sin que la lectura sufriera mermas. Pero esto es no es así; son numerosísimas las ocasiones en que el texto en letra grande va seguido de los dos puntos que reclaman la continuación en el texto en letra pequeña que sigue a continuación, con lo cual se incumple lo propuesto en las indicaciones prácticas. Un ejemplo de ello puede ser lo que sucede en el n. 964, como también en los n. 972, 1.007, 1.042,... entre otros muchos posibles.

Ello resulta aún más llamativo cuando se relega a párrafos publicados con letra pequeña, y por tanto, con carácter de afirmaciones complementarias, lo que constituyen datos notables y dignos de ser tenidos en cuenta, como es el hecho de que la reconciliación comporta también la reconciliación consigo mismo y con los demás (n. 1.469; también podría decirse lo 
mismo del n. 1.737). Otro tanto podría afirmarse del n. 2.268, en el que se reserva el uso de la letra pequeña para hablar de los "crímenes especialmente graves", ya que no da la impresión de que la materia tratada guarde proporción con la condición de afirmación "complementaria" que se le otorga. Y aún resulta más contraproducente, cuando se comprueba, como tendremos ocasión de verificar, que se emplea la letra grande, para afirmaciones absolutamente secundarias y perfectamente discutibles, que en nada empañan lo fundamental de la fe cristiana, pero que a los redactores les han parecido no datos complementarios, sino básicos. Pedir más rigor en este punto no es simplemente un mero ejercicio de maquetación editorial, sino que lo que en ello va implicado es un principio bastante más notable, cual es el de jerarquía de verdades (Unitatis redintegratio, 11), con arreglo al cual, todas las afirmaciones de la fe no tienen el mismo entronque con lo nuclear del mensaje cristiano.

$\mathrm{El} \mathrm{n} \mathrm{n}^{\circ} 22$ se refiere a los resúmenes que figuran al final de cada unidad temática, a modo de conclusiones que tienen "como finalidad ofrecer sugerencias para fórmulas sintéticas y memorizables". Esto, en el mejor de los casos, es un "desideratum" muy lejano a la realidad y a las más mínimas exigencias de índole pedagógica. Entre las fórmulas sintéticas y memorizables aparecen parráfos breves ( $\left.\mathrm{n}^{\circ} 317\right)$ junto a otros largos, larguísimos ( $\left.\mathrm{n}^{\circ} 1.053\right)$; se incluyen citas, unas veces sólo como referencias $\left(n^{\circ} 629\right)$, en tanto que otras veces son las expresiones literales ( $\left.\mathrm{n}^{\circ} 940\right)$; entre esas citas literales hay frases de la Biblia ( $\mathrm{n}^{\circ} 2.773$ ), o de la oración eclesial ( $\mathrm{n}^{\circ} 380$ ), junto a fragmentos de cánones ( $\mathrm{n}^{\circ}$ 936); también hay esquemas articulados en diversas partes (hasta con cinco subdivisiones) ( $\mathrm{n}^{\circ} 1532$ ); e incluso, aparecen frases latinas, unas veces traducidas $\left(\mathrm{n}^{\circ} 1.015\right)$, y otras sin traducir (n. 1.592). Como puede apreciarse, constituye un heterogéneo conjunto de diversas y dispares afirmaciones, en las que, sin entrar en la calidad de las afirmaciones contenidas, al menos desde el punto de vista pedagógico, no hay más remedio que formular serias reservas sobre su oportunidad como fórmulas sintéticas y memorizables ${ }^{14}$.

En otra ocasión, aparece, descolgada, una frase de línea y media de extensión, que no se aclara si tiene o no la condición de "resumen", puesto que no aparece precedida del titulillo correspondiente, pero en la que sí se

14 No sé exactamente cómo hay que entender, desde el sentido común, la indicación que hace el ya citado Dossier informativo, que en su página 22 precisa que "en él se evitan las indicaciones pedagógicas y las aplicaciones metodológico-didácticas", afirmación que se repite en la pg. 29. Sinceramente creo que en lugar de esa postura aséptica en cuanto a elementos pedagógicos, unas dosis de la más elemental pedagogía no hubieran hecho ningún daño en aquello que se pretende encomendar a la memoria. 
emplea la misma letra cursiva con que figuran el resto de los resúmenes: es la frase final del n. 152. Se puede estimar como resumen, o no hacerlo así. Y lo curioso es que sí que tiene tal carácter de resumen, y es precisamente uno de los más conseguidos, pues dice las cosas en forma breve, clara y sencilla.

Se produce, además, otro fallo notable en la presentación literaria, puesto que en muchas de las citas (especialmente las que se hacen en letra pequeña), se ha omitido con una frecuencia abundantísima el empleo de las comillas; esto conlleva el que se sobreentienda que todo el párrafo reproducido es el objeto de la cita (n. 28). En otros casos, sí se utilizan (n. 32, 173), lo que no da lugar a interpretaciones equívocas. Ello ha sido consecuencia de una decisión en la presentación, que ha preferido eliminar las comillas antes que utilizarlas, con lo cual se siembra el desconcierto. La prueba aparece cuando las comillas se utilizan mal, como es el caso del n. 1.825, donde sí se colocan al comienzo de la cita, mientras que se omiten al final (cabría pensar en una simple errata); pero resulta confuso en las referencias del n. 2.042, en que no se sabe si son citas textuales, o simplemente según el sentido, y si tales citas están reproduciendo el Código de Derecho Canónico occidental, o el Corpus canonum Ecclesiarum Orientalium; además, en otras ocasiones, resulta desconcertante y equívoco, pues se emplea en un caso y en otro no, lo que obliga a una consulta necesaria, o a suponer un lector lo bastante ducho como para no dudar: es el caso del n. 2.122, en el cual aparece el empleo de comillas para reproducir una frase del Código de Derecho Canónico, y luego no se emplean para una referencias bíblicas; como en ocasiones se han reproducido frases textuales, acompañadas de la cita al final de las mismas, cabe suponer que aquí se trata también de cita textual, cuando resulta que no es así. Algo tan sencillo, tan práctico y tan clarificador como el uso de las comillas deviene un factor perturbador debido a un mal uso sistemático. Es lástima que haya que señalar un fallo tan fácilmente evitable, y que hubiera contribuído a la claridad conjunta ${ }^{15}$.

\section{La cuestión de las fuentes empleadas}

Progresivamente voy pasando de las cuestiones más superficiales o triviales, a las más importantes. Tal es el caso de las fuentes que el Catecismo utiliza. El amplio índice de textos, que aparece en las páginas finales, da cuenta de ello. Me limito a recordar que en el empleo de las fuentes utiliza-

15 Tampoco es la primera vez que pasa esto mismo, pues en CONFERENCIA EPISCOPAL ESPAÑola, Esta es nuestra fe. Esta es la fe de la Iglesia, ya ocurrió lo mismo, lo que acarrea un uso deficiente y devaluador del propio instrumento que se utiliza. 
das, "el texto se nutre abundanitemente de la Sagrada Escritura, de la Tradición occidental y oriental, de la Iglesia (en particular de los Padres), de la Liturgia, del Magisterio, del Derecho canónico, de la vida y las enseñanzas de los santos" ${ }^{16}$. En principio, ello supone una abundante riqueza, de la que es preciso alegrarse. No aparece muy claro, con todo, el matiz diferenciador entre "Tradición" y enseñanza de los "Padres" o de los "santos", e incluso, apurando, del "Magisterio", puesto que todo ello constituye la Tradición.

No pretendo detenerme en el análisis pormenorizado de todas y cada una de las fuentes citadas, porque entonces la cuestión llevaría a una extensión superior a la prevista. Sin embargo, sin desdecirme de lo que supone una considerable riqueza, la sensación que se desprende en ocasiones es que la abundancia de fuentes referidas podría haberse reducido, en aras de la claridad, y que la excesiva proliferación de las mismas no añade nada a las afirmaciones fundamentales, cuando están suficientemente justificadas, sin necesidad de nuevas apoyaturas; en ocasiones, la acumulación de citas produce una cierta sensación de agobio. Pero lo que es más importantes es que en el conjunto del Catecismo, se presenta un contenido demasiado tradicional y obsoleto, arropado de numerosas referencias bíblicas y conciliares, lo que parece prestarle un aire de renovación y actualización, que no siempre tiene.

Hay un dato que me ha llamado poderosamente la atención. No siempre, pero sí en algunas ocasiones particularmente significativas, la versión castellana que aparece reproducida de la Biblia, de los documentos conciliares, del Catechismus romanus, o de otras fuentes, no coincide con las versiones habituales más en uso. Se desprende la sensación de que el equipo responsable de la edición castellana no se ha sentido siempre cómodo con las versiones que sustentan la fe cristiana de manera habitual, y han tenido que recurrir a hacer sus propias traducciones ${ }^{17}$, lo que implica otros acentos insospechados en las fuentes aducidas; en ocasiones ello conlleva una mayor claridad, lo cual es de agradecer, mientras que en otros momentos se han reforzado acentos jerárquicos. El ejemplo más clarificador de lo que acabo de afirmar se encuentra en el n. 892 del Catecismo, donde a propósito de la misión de enseñar que corresponde a los obispos, se dice que "a esta enseñanza ordinaria, los fieles deben 'adherirse...con espíritu de obediencia religiosa' (LG 25)”. Para los conocedores del latín, la frase, según el texto oficial

16 Dossier informativo, Vaticano, Libreria Editrice Vaticana, 1992, 22.

17 No de otro modo se puede explicar que en ocasiones los textos citados sean expresiones literales de versiones usuales de las fuentes aducidas (por ejemplo, el caso de Dei Verbum, 9, citado en los n. 80-81), en tanto que otras veces rehusen las traducciones usuales para recurrir a otra traducción. 
es: "fideles autem in sui Episcopi sententiam de fide et moribus nomine Christi prolatam concurrere, eique religioso animi obsequio adhaerere debent". Traducir, como el Catecismo hace, "obsequio" por "obediencia" no resulta absolutamente inadecuado, pero el texto latino no emplea la palabra "oboedientia", que no dejaría lugar a dudas; y la versión castellana que tengo a la vista ${ }^{18}$ traduce el término latino "obsequio", en esta frase, por "respeto"; en la frase que le sigue, por "obsequio", y en la que concluye el párrafo que viene a continuación, por "sumisión”. Entre "obsequio", "respeto", "sumisión", y otras expresiones similares (aceptación, adhesión, asentimiento, ...) y "obediencia" yo percibo una distancia muy nítida.

No querría detenerme en cada cita con la pausa y el espacio dedicada a la que precede. Pero no es posible dar por terminada la cuestión de las fuentes a las que el Catecismo acude. Otras veces, acude a documentos conciliares, pero, a mi entender, lo hace mal, como ocurre en el $\mathbf{n}$. 871, donde suministra una definición de "fieles cristianos: jerarquía, laicos, vida consagrada", en que cita al Código de Derecho Canónico, c. 204, que a su vez es casi calco de LG 31. Si lo que se pretendía era hablar de los "laicos", el texto está bien aportado; pero si, a lo que parece, se pretende hablar de "cristianos", por tanto, todos los cristianos, debería haberse citado LG 14, puesto que el texto reproducido en el Catecismo se refiere directamente a los laicos. También se reproducen textos conciliares (además de otro de Evangelii nuntiandi) en los n. 908-913, 954-959, 967-970, pero en realidad lo único que se hace es repetir, sin más, esos párrafos literales, sin añadir absolutamente nada ${ }^{19}$, ningún tipo de explicación, aclaración o profundización: para eso, con remitir a la lectura de los documentos conciliares, hubiera sido suficiente, sin necesidad de elaborar este nuevo libro.

Más notable, sin lugar a dudas, es el n. 966, donde una engorrosa omisión -no de otro modo puede entenderse- ha eliminado que María "fue asunta en cuerpo y alma a la gloria celestial", al citar a LG $59^{20}$.

Otro dato desconcertante es que, al citar a San Ignacio de Antioquía se reproducen sus palabras traducidas al castellano, menos en los n. 1.010 y

18 Concilio Vaticano II, Constituciones. Decretos. Declaraciones., Madrid, BAC, $1966^{4}$, con el nuevo texto latino oficial; coincide en todo con la versión castellana de la edición tercera del mismo año; en cambio no existe coincidencia con la edición primera, de 1965.

Sin embargo, en otras ocasiones, los textos conciliares que no han sido objeto de nueva versión, por parte de los redactores, o por parte del equipo de traducción al castellano, sí coinciden con esta versión.

19 Tampoco añade absolutamente nada a la primera afirmación del n. 982 el texto que sigue a continuación, tomado del Catechismus romanus.

20 También en esta ocasión se puede observar la divergencia entre la traducción del Catecismo y las versiones usuales de los documentos conciliares.

Por su parte, JOSE LUIS LARRABE, ya hizo notar ("Vida Nueva", no 1.879, 30 enero 1993, 4) semejante omisión, aparte de otras precisiones al texto. 
1.549, donde además aparecen en griego ¿A qué obedece este doble juego? $\mathrm{Si}$ las afirmaciones que constan en estos números son destacables, ¿no lo son también las demás? ¿Por qué no poner todas bilingües?; ¿o por qué no traducirlas todas, sin más? No veo claro el proceder diverso en cada ocasión; pero el Catecismo tampoco lo explica ${ }^{21}$.

Habría que hablar también de los momentos en que la frase citada está alterada, sin que ninguna indicación o advertencia lo haga notar al lector: esto induce a atribuir a un autor lo que realmente no escribió. Puede servir de ejemplo la cita de San Justino que consta en el n. 2.174, en la cual se interpola un paréntesis que no pertenece al texto original. Tampoco quiero dejar de notar, en la misma línea, que en otros momentos, aunque no se haya modificado para nada el texto citado, hubiera sido totalmente necesaria una aclaración, para que el lector del Catecismo, si no puede acceder a la consulta directa, pueda, al menos, situar el texto en su contexto y percibir el adecuado sentido de lo que se cita y reproduce. Tal es el caso del n. 1.937 donde aparece una cita (por supuesto, sin comillas) de Santa Catalina de Siena en su Diálogo; da la sensación de que las afirmaciones las hace Catalina de Siena, siendo así que ella conversa con Dios, y que estas frases están puestas en labios de Dios. Y esto, por desgracia, no aparece claro.

Quiero terminar destacando una curiosa y singular excepción en la cuestión de las fuentes citadas, ya que, como anoté antes, se acude al patrimonio eclesial en sus diversas manifestaciones, menos en una ocasión donde se incorpora, indirectamente, una cita no cristiana, si bien haya sido asumida por Santo Tomás de Aquino; éste remite a Aristóteles, a propósito de la prudencia, y así consta en el Catecismo en el n. 1.806. Rara avis. Ahora bien, a propósito de esta excepción, cabe preguntarse que si no ha habido dificultad en remontarse hasta el pagano Aristóteles al acudir a ciertas fuentes del Catecismo, cómo no se han incorporado, además, otra serie de pensamientos de autores no cristianos, o de autores cristianos no católicos, que no estuvieran en contradicción con las afirmaciones de la fe cristiana ${ }^{22}$.

21 Además, la expresión griega de la carta citada de Ignacio de Antioquía habla de que el obispo es "tipon tou patrós", que aparece traducido como "figura del Padre" (D. RUIZ Bueno, Padres apostólicos. Texto bilingüe completo, Madrid, BAC, 1950, 469), en tanto que el Catecismo lo hace como "imagen viva de Dios Padre".

22 Por ejemplo, el catecismo del Episcopado alemán, titulado Glauben-leben-handeln, (versión castellana Nuevo catecismo católico. Creer.vivir.obrar, Barcelona, Herder, 1971), no tuvo inconveniente en incluir en sus páginas numerosas aportaciones de todo tipo de procedencias, sin que por ello se resintiera la fe católica.

Personalmente, no tengo nada contra Aristóteles, pero me llama la atención que se le haya concedido un estatuto "para-católico", que a otros se les ha negado. 


\section{El espinoso problema del lenguaje.}

En el lenguaje, el fondo y la forma se unen, ya que se trata de abordar conjuntamente lo que se dice y cómo se expresa.Y la verdad es que, en términos generales, el Catecismo es un libro de lectura difícil, debido tanto al contenido de los temas abordados, como al tecnicismo de querer ajustar y matizar las expresiones, así como al hecho de que en su redacción hayan intervenido muchas manos, y esto se ha plasmado en estilos y formas de expresión muy diversos; a ello hay que añadir, a mi modo de ver, otro aspecto nada despreciable, cual es el hecho de que se haya querido presentar una doctrina enfocada con unos criterios generalmente superados, pero utilizando un lenguaje renovado (por ejemplo, en la incorporación de citas) lo que ha producido desajustes chirriantes desde el punto de vista de la claridad expositiva.

No hay más remedio que recordar el principio reclamado por Catechesi tradendae, 59 que alude al uso de un "lenguaje adecuado" a la hora de presentar la fe. Claro está que la pregunta salta inmediatamente: adecuado, ¿para quién? Porque en un Catecismo que cuenta con unos destinatarios tan plurales y diversos, no resulta fácil "adecuarse" a todos. De ahí que a la vista de las dificultades de lenguaje, el asunto de los destinatarios vuelva a cobrar toda su importancia y sus consecuencias. Cuando el Dossier informativo habla de las cualidades que reúne la obra, afirma que "se caracteriza por la esencialidad, la concisión, la sobriedad, la incisividad, la claridad" ${ }^{23}$. Yo me permito discrepar de la última apreciación. En conjunto, me parece una obra de lectura difícil, tanto por la extensión, por la tónica o estilo empleado. Pero, además, existe el suficiente número de comprobaciones como para poder verificar lo enunciado.

Voy a comenzar por dos ejemplos paradigmáticos de la dificultad, uno largo, y el otro breve. El primero, el amplio, consta en el n. 57; en el contexto inmediatamente anterior, viene hablado de la alianza que Dios pacta con Noé (nada se dice del género literario mítico, propio de los once primeros capítulos del Génesis, sino que se deja correr como si de una narración histórica se tratara), y en el número aludido, casi kafkiano, se dice lo siguiente: "Este orden a la vez cósmico, social y religioso de la pluralidad de las naciones (cf Hch 17,26-27), confiado por la providencia divina a la custodia de los ángeles (cf Dt 4,19: Dt [LXX], 32, 8), está destinado a limitar el orgullo de una humanidad caída que, unánime en su perversidad (cf Sb 10,5), quisiera hacer por sí misma su unidad a la manera de Babel (cf Gn 11,4-6). Pero, a

23 Dossier informativo, Ciudad del Vaticano, Libreria Editrice Vaticana, 1992, 21. 
causa del pecado (cf $\operatorname{Rm} 1,18-25$ ), el politeísmo así como la idolatría de la nación y de su jefe son una amenaza constante de vuelta al paganismo para esta economía aún no definitiva". Llevaría demasiado tiempo y espacio analizarlo con minuciosidad; me limito a señalar los aspectos más notables. El orden al que empieza refiriéndose, parece ser la alianza establecido con Noé; se le califica de "cósmico, social y religioso", con tres adjetivos desconcertantes. Se afirma que está confiado a la custodia de los ángeles, citando textos que nada tienen que ver con el presente contexto del libro del Génesis. Y se dice que ese orden o alianza establecida tiene como finalidad "limitar el orgullo de la humanidad caída que, unánime en su perversidad quisiera hacer por sí misma su unidad a la manera de Babel": si lo que han pretendido los redactores es referirse el episodio de la construcción de la torre de Babel, han encontrado la fórmula más obscura, retorcida y difícil para hacerlo. Después habla del "politeísmo y la idolatría de la nación y de su jefe", como amenaza para esta economía. ¿De qué nación se trata?, ¿quién es su jefe?: imposible saberlo. ¿Cómo hablar de "vuelta al paganismo", cuando aún Dios no ha dado a conocer los primeros y progresivos datos de una revelación que se va enriqueciendo hasta llegar a su plenitud? De verdad que todo el número parece una enorme e inexplicable charada indescifrable. Yo he pedido a varias personas, a varios teólogos, con sus correspondientes especializaciones, que me proporcionaran una aclaración de este desafortunado n. 57. Y hasta ahora no lo he conseguido. Lo más fácil, sin duda, sería olvidarse enteramente de él y hacer otra redacción diversa.

El otro ejemplo de confusión es el que he anunciado como breve, y ciertamente lo es. Pero su lenguaje críptico, por el empleo de tecnicismos, lo hace asequible únicamente a los conocedores a fondo de la liturgia. Se trata del $\mathrm{n}$. 1106, que dice: "Junto con la Anámnesis, la Epíclesis es el centro de toda celebración sacramental, y muy particularmente de la Eucaristía". No me sirve de consuelo, ni resuelve la intrínseca obscuridad de lenguaje el hecho de que en el n. 1103 se dé una larga explicación de qué es Anámnesis (o "Anamnesis", sin acento), de la que siete líneas más adelante se aclara que "hace memoria"; ni tampoco que el n. 1105 explique qué es Epíclesis (o Epiclesis, igualmente sin acento), equivalente a "invocación sobre". Porque si para hacer afirmaciones sobre la celebración eclesial es preciso verse obligado a tener una formación de nivel superior, o consultar un glosario de términos, no se ha conseguido el ideal que se pretendía de un lenguaje adecuado.

Por desgracia, estos no son más que dos ejemplos. Si no dijera más sobre este aspecto, estoy seguro que habría quien pensara que he rebuscado con malévola intención los dos únicos lugares en que esto se produce. Y que esto he querido elevarlo a conclusión general. Por ello, me veo obligado, 
aunque sea más someramente, a prolongar la exposición de las dificultades del lenguaje.

El n. 248 (por razón de la materia, la Trinidad, así como pör el lenguaje empleado) resulta también difícil. El empleo de lenguaje filosófico al hablar de causa primera y causas segundas hace también obscuro a muchos lectores los n. 306-307 ${ }^{24}$.

También me parece obscura la primera frase del n. 877, a propósito de la colegialidad episcopal: "De igual modo es propio de la naturaleza sacramental del ministerio eclesial tener un carácter colegial"; pero aún es más confuso el n. 878 en la frase que dice "cada uno [de los obispos] ha sido llamado personalmente (...) para ser, en la misión común, testigo personal, que es personalmente portador de la responsabilidad ante Aquel que le da la misión, que actúa 'in persona Christi' y en favor de personas: 'Yo te bautizo en el nombre del Padre...'; 'Yo te perdono'". Porque no está claro que "Aquél" (y no Aquel, sin acento) se refiera al Papa que nombra y confía una misión a cada obispo, o si se refiere a Dios. No parece que haya que referirlo a Dios, puesto que añade que el misterioso 'Aquel' actúa 'in persona Christi'; y la verdad es que no creo que, en una teología medianamente sana, Dios actúe en lugar de Cristo. Por tanto, si 'Aquel' se refiere al Papa, no hay más remedio que admitir que cada obispo es responsable ante el Papa, dato éste último de difícil justificación. Yo creía -y sigo creyendo- que cada obispo es responsable ante Dios.

A pesar del esfuerzo por conseguir la claridad, estimo que en el n. 948, a propósito de la comunión de los santos, el doble sentido de la palabra latina "sanctis" confunda a más de una persona ${ }^{25}$. Tampoco me parece claro, excepto para personas con un nivel cultural notable, el título que precede al n. 972 y que dice: "María, icono escatológico de la Iglesia". Hubiera valido la pena el esfuerzo de exponerlo de manera más inteligible.

En los n. 978 y 979, que citan al Catechismus romanus se emplea al final del n. 978 la palabra "concupiscencia" (igual que en el texto latino); y, en cambio, al comentarlo en la línea siguięnte (ya en el n. 979) se substituye por "inclinación al mal". Esto no supone obstáculo mayor para quien ya lo conoce; pero no son pocos los que no relacionan el primer término con el segundo ${ }^{26}$.

24 Algo parecido ocurre en el empleo de una filosofía dualista de alma y cuerpo como realidades diversas que se juntan o separan, para hablar de la vida y de la muerte (n. 997), aunque en este caso no existen radicales obstáculos en la expresión empleada.

25 En el n. 1.331 se refiere a uno de estos dos sentidos, el de "las cosas santas", y además de ponerlo en castellano, lo expresa en griego ("ta agia") y en latín ("sancta").

26 En el n. 2.515 se afirma que concupiscencia puede designar "toda forma vehemente de deseo humano", y más en particular, el sentido teológico de "apetito sensible que contraría 
En el n. 981, el empleo de las expresiones acuñadas "el poder de las llaves" y "las llaves del Reino" no pasan de ser términos metafóricos, que no son suficientemente explicados, ya que ni en todo el apartado (n. 981-983), ni en el que le precede, es decir, en todo el artículo completo se remite a Mt. 16, 19, que es donde aparece la expresión; en consecuencia, quien no tenga la suerte de haberla conocido previamente, tendrá que hacer cábalas para descifrarla.

A lo largo de la segunda parte del Catecismo, a partir del n. 1076, aparece con frecuencia un término en el que percibo que habrá no pocas dificultades para numerosas personas: el de "economía sacramental" ¿Me equivoco al pensar en más de una persona concreta que percibirán en dicho término los asuntos monetarios relacionados con los sacramentos?

En el n. 1.266, para hablar de la novedad que supone la vida cristiana para el bautizado, se habla de "virtudes teologales", "dones del Espíritu Santo" y "virtudes morales", y concluye: "Así todo el organismo de la vida sobrenatural del cristiano tiene su raíz en el santo Bautismo". Estoy firmemente convencido de que esto mismo podría haberse expresado con mucha mayor nitidez.

Para quien desconozca qué es la anáfora, dudo seriamente que la explicación que aparece en los n. 1.352-1.354 se lo aclare, entre otras cosas, porque ni siquiera aparece claro que "anáfora" es equivalente en el uso litúrgico a "plegaria eucarística", subdividida, a su vez en una serie de partes (No queda mucho más explícito en el n. 1.371. Hay que ir al n. 2.770 para encontrar la siguiente aclaración: "Situada entre la Anáfora [Oración eucarística] y la liturgia de la Comunión...").

El fixismo en fórmulas acuñadas, que se repiten, hace que vayan perdiendo significado para el hombre actual, ya que tales fórmulas están vinculadas a una terminología filosófica, de la que han recibido su significado. Cuando tal terminología filosófica resulta ajena a muchos de nuestros contemporáneos, no hay más remedio que acertar a reformular -por supuesto, sin traicionar- la fe cristiana. De ahí que haya que hacer un esfuerzo por encontrar expresiones válidas e inteligibles en lugar de repetir que Cristo está presente en la eucaristía "verdadera, real y substancialmente" (n. 1.374).

El n. 1.617 incluye una expresión que yo jamás había oído o leído, cuando al referirse al bautismo habla del "baño de bodas". Remite a Ef. 5, 25-26 (“...Cristo amó a su Iglesia y se entregó por ella, para santificarla, purificándola, mediante el lavado del agua con la palabra”) donde tal expresión no

la obra de la razón humana". Sigo pensando que resulta más esclarecedor hablar de "inclinación al mal". 
aparece, ciertamente. Y el "baño de bodas" me parece que complica, más que aclara lo del "lavado del agua con la palabra".

A propósito de la libertad, el n. 1.749 incluye la expresión de que "el hombre es padre de sus actos". A mí me parece mucho más sencillo, claro y directo afirmar que es "responsable" de sus actos.

Por otro lado, la dificultad que encuentro en el n. 1.865 no es tanto la del uso de expresiones obscuras, como en otros casos, sino la de una forma de redacción con arreglo a la cual, se concede vida propia al pecado, algo así como si tomara sus propias decisiones: hubiera sido preferible hablar del hombre pecador que siente la tendencia a ratificarse en su propia postura.

Pasando al n. 1.991, la justificación es definida como la "acogida de la justicia de Dios por la fe en Jesucristo. La justicia designa aquí la rectitud del amor divino". Hubiera sido más claro y simple decir que es la santidad de Dios, de la que participa el hombre. Parece como si hubiera un no confesado propósito de decir las cosas de manera difícil cuando se puede expresar más fácilmente.

El n. 2.272 plantea el tema del aborto directamente provocado, en relación al cual se recuerda la disposición de incurrir en "excomunión latae sententiae", y para explicar el tecnicismo no traducido, se añade: "es decir, 'de modo que incurre ipso facto en ella quien comete el delito"'. Un término técnico en latín, queda aclarado con otro tecnicismo también en latín, y se da por bien expuesto el tema.

Desbordando todas las previsiones imaginadas y por imaginar, los responsables de la edición castellana del Catecismo abordan en el n. 2.337 el tema de la castidad, y tras un párrafo introductorio no tienen inconveniente en largar la siguiente e inexplicable frase: "La virtud de la castidad, por tanto, entraña la integridad de la persona y la integralidad del don". A continuación, en sendos apartados, se explica lo que entienden por "integridad de la persona" y por "integralidad del don", que resulta ser "la integralidad del don de sí" (n. 2.346-2.347). Confieso abiertamente que no entiendo qué se quiere decir con "la integralidad del don". He consultado unos cuantos diccionarios castellanos y no he encontrado la referida palabra, que no existe en nuestra lengua. He consultado también un diccionario francés que, además de incluir el vocablo "intégrité", traduce el término "intégralité" por "integridad, globalidad, totalidad". Los responsables del equipo traductor de la edición castellana se inventan una palabra, que en nada difiere de la que ya existe ("integridad") y que ellos mismos han utilizado, y se quedan tan anchos. Decididamente hay que darles un suspenso en la labor desarrollada. Y todo para decir que la castidad rectamente entendida no supone una postura egoísta, sino de apertura y enriquecimiento de los demás. 
En el n. 2.598 aparece una frase sorprendente en extremo, cuando afirma que "el drama de la oración se nos revela plenamente en el Verbo que se ha hecho carne y que habita entre nosotros". De verdad que no veo sentido ni justificación suficiente para hablar del "drama de la oración". Cierto es que cuando un creyente se dirige a Dios desde una situación angustiosa, su oración no puede por menos verse teñida de tintes dramáticos, trágicos; pero no siempre la oración es así (el propio Catecismo trata de presentar diversos modelos). $\mathrm{Si}$, por tanto, la oración no siempre es dramática, tampoco percibo que la situación de la oración dramática haya de relacionarse con la encarnación de Jesús, pues, si bien su vida terminó humanamente de forma trágica, ello no equivale a hacer extensible esa categoría dramática para toda la vida de Jesús sobre la tierra.

Como se ve, son unos cuantos ejemplos, algunos de ellos de notable entidad, que muestran en el Catecismo un lenguaje obscuro, difícil, o críptico, cuando se podría haber hecho un esfuerzo sensible en aras de la claridad, sin empañar, para nada la calidad de lo presentado. Podrían espigarse más ejemplos, como también podría aducirse numerosos párrafos en que predomina la claridad expositiva. Pero no creo que se trate de organizar una tabla clasificatoria de aciertos y fallos expositivos, sino dejar constancia, con dolor y sentimiento sincero de que las numerosas deficiencias empañan' el resultado pretendido.

\section{Defectos en la redacción.}

En el n. 82 se reproduce un texto conciliar tomado de Dei Verbum, 9 que hace referencia a la complementación entre la Escritura y la Tradición ${ }^{27}$. Aquí sí aparece la referencia expresa. Pero no sucede lo mismo en el número anterior, el n. 81, en el que figuran dos frases entrecomilladas en que no se cita procedencia. La explicación es sencilla. Tanto el n. 81, como el n. 82 corresponden al párrafo de Dei Verbum, 9, pero, por no sé qué extraña maniobra, se ha preferido no reproducir el texto seguido, que en su expresión original dice literalmente lo mismo que el Catecismo reproduce en el n. 81 sobre la Escritura y la Tradición, y continúa: “...la difundan fielmente en su predicación. Por eso la Iglesia no saca exclusivamente de la Escritura la certeza de todo lo revelado. Y así ambas se han de recibir...". Pero este texto (del que he resaltado lo que ha sido omitido en el Catecismo), aparece con la

27 Por cierto, el texto está alterado, pues dice: “... y así se han de recibir y respetar con el mismo espíritu de devoción”, cuando en realidad debe decir: "... y así ambas se han de r’’cibir...". 
siguiente redacción en los números citados: “...y la difundan fielmente en su predicación. De ahí resulta que la Iglesia, a la cual está confiada la transmisión y la interpretación de la Revelación, no saca exclusivamente de la Escritura la certeza de todo lo revelado. Y así se han de recibir ...”. ¿Qué extraña e inconfesada preocupación ha guiado las plumas y las mentes de los redactores para querer decir más que el documento conciliar? ¿No estaba bastante claro que la Iglesia tiene la obligación y la responsabilidad de ser intérprete fiel de la revelación? Mi experiencia me dice que lo mostrado no es una errata de imprenta.

Ya mostré con anterioridad el corrimiento que los redactores del Catecismo han pretendido dar al texto de Lumen Gentium, 25 al desplazar el término latino "obsequium" hasta el castellano "obediencia". Pero en esa ocasión han tenido la precaución de evitar que aparezca expresamente el texto latino, pues así la maniobra puede pasar desapercibida. En cambio, en el n. 967 del Catecismo han hecho justamente lo contrario, pues recuerdan a María como "la figura ["typus"] de la Iglesia (LG 63)". El texto latino dice: "Deipara est Ecclesiae typus", y lo traduce por "la Madre de Dios es tipo de la Iglesia". No se han conformado con citar el texto castellano, sino que han acudido al latino para reforzar su versión. ¿Por qué no han tenido la valentía de hacer siempre lo mismo? Por otra parte, si es suficiente con presentar la traducción castellana para que la fe resulte adecuadamente expresada, ¿qué necesidad existe de buscar apoyaturas en el texto latino, como texto seguro y modélico, al que unas veces se acude y otras no? Cualquier lector inteligente percibe con nitidez que no se trata únicamente de una cuestión de redacción correcta o incorrecta, sino que se ventilan contenidos y acentos sutilmente inducidos.

Parece mentira que en la cita de la poesía de Santa Teresa titulada "Nada te turbe" (n. 227), el Catecismo, precisamente en la versión castellana, haga de dos versos uno, pues omite la barra de separación entre estos dos versos: “...la paciencia / todo lo alcanza..." Es lástima que esta sencilla omisión induzca a un error; y no parece que se trate simplemente de una errata, porque la disposición de la estrofa llevaría a creer que está constituida por ocho versos, con la poco ortodoxa construcción de siete versos pentasílabos, y uno decasílabo.

Pero parece que la mala fortuna se ha cebado también con Santa Teresa del Niño Jesús, ya que en el largo texto de su autobiografía, no alcanzo a saber por qué unas frases están con letra redonda, mientras que otras están con cursiva, además de otras que figuran en cursiva mayúscula (n. 826). La verdad es que resulta una extraña manera de citar, que no es aclarada en parte alguna del Catecismo. 
La redacción del n. 1.037 en sus primeras líneas es especialmente desafortunada. El texto dice: "Dios no predestina a nadie al infierno (cf DS 397;1567); para que esto suceda es necesaria una aversión voluntaria...". El inadecuado empleo de "esto" tendría que haberse referido a una frase que no aparece, y que podría ser, más o menos, la siguiente: "para que alguien vaya al infierno". Pero, como tal frase hay que suponerla, da la sensación de que se está refiriendo a la frase inmediatamente anterior, en cuyo caso, la totalidad de la frase quedaría de la siguiente forma: "Dios no predestina a nadie al infierno; para que Dios predestine a alguien al infierno es necesaria una aversión voluntaria...". Y entonces topamos con que la lectura que el texto materialmente propone invita a aceptar que efectivamente existe predestinación para el infierno. Unos leves y oportunos retoques hubieran soslayado tan deficiente sugerencia.

A propósito del bautismo y la fe implicada en el mismo, aparece la redacción siguiente en el n. 1.255: "Para que la gracia bautismal pueda desarrollarse es importante la ayuda de los padres. Ese es también el papel del padrino o de la madrina". Creo que se devalúa con esta redacción el papel de los padres, que queda reducido a algo que es simplemente importante, pero no necesario, ni determinante, ni fundamental.

El Catecismo incurre en un equívoco cuando no da las explicaciones oportunas para entender adecuadamente lo que afirma. En relación con la confirmación, señala que el obispo procede a consagrar el crisma en la disciplina occidental, mientras que en la oriental esta función le corresponde al "Patriarca". Pero no se aclara quién es el patriarca, ni cual es su función. En las dos ocasiones en que se emplea la palabra en el sentido de referirse al patriarca de la Iglesia oriental (n. 1.297 y 1.312) nada contribuye a explicar el concepto. Pero si alguien tiene la idea de buscar alguna orientación en los diversos números del Catecismo, localizados por la voz "patriarca" del índice temático, se encuentra con la sorpresa de que todos los demás números reseñados se refieren a los patriarcas del pueblo de Israel. Con lo cual nada se le resuelve.

A propósito de la confirmación, se produce en unos cuantos números del Catecismo una situación extraña, a la que se va gradualmente llegando. El n. 1.289 comienza el asunto con una disparatada redacción, pues alude al nombre oriental de crismación, "unción con el crisma, o myron, que significa "crisma". ¿A qué viene ese juego de palabras entre "crisma" y "myron" para venir a decir que "myron" significa "crisma". Ambas expresiones griegas son equivalentes, y tienen el significado de aceite, ungüento, óleo, bálsamo. Con haber dicho: "crisma" o su equivalente "myron", hubiera sido más que suficiente, y todo hubiera quedado perfecto, teniendo en cuenta que "crisma" se 
ha integrado normalmente al idioma castellano. Pero no contentos con tan defectuosa redacción, los autores insisten en el n. 1.290 en utilizar la palabra "myron", como si no hubiera equivalente en castellano; y de nuevo vuelven a las andadas en el n. 1.297 en que la terquedad hace aparecer reiteradamente la palabra "myron". ¿No se trataba de hacer una traducción al castellano? ¿Por qué, entonces, empecinarse en traducirlo a medias, no empleando la palabra plenamente aceptada como castellana, y repitiendo con fijación un vocablo no castellano?

No me cabe en la cabeza el que se haya dado de paso una redacción tan extravagante como la que figura en el n. 1.421, que reproduzco: "El Señor Jesucristo, médico de nuestras almas y de nuestros cuerpos, que perdonó los pecados al paralítico y le devolvió la salud del cuerpo (cf Mc 2, 1-12), quiso que su Iglesia continuase, con la fuerza del Espíritu Santo, su obra de curación y de salvación, incluso en sus propios miembros. Esta es la finalidad de los dos sacramentos de curación: del sacramento de la Penitencia y de la Unción de los enfermos" (el subrayado es mío). ¿Desde cuando es válido afirmar que los sacramentos son incluso para los miembros de la Iglesia? ¿Para quién están destinados, si no, los sacramentos? ¿O es que a partir de ahora también pueden recibir estos dos sacramentos los no católicos? Un poco de seriedad, señores.

El n. 2.688 incluye la afirmación de que "la memorización de las oraciones fundamentales ofrece una base indispensable para la vida de oración". Yo creo que hubiera sido preferible haber substituido el adjetivo "fundamentales" por "comunes".

Ya me he referido antes al n. 2.770 en que se muestra el equivalente de "anáfora" con "oración eucarística"; pero si esto hay que aplaudirlo sin reservas, no sucede otro tanto con el resto de la frase, pues a propósito de la ubicación del rezo del padrenuestro en el transcurso de la celebración de la eucaristía, dice: "Situada entre la Anáfora (Oración eucarística) y la liturgia de la Comunión, recapitula, por una parte, todas las peticiones e intercesiones expresadas en el movimiento de la epíclesis, y por otra..." También he tenido oportunidad de referirme al nada claro concepto de "epíclesis" (o epiclesis), pero además, la expresión "movimiento de la epíclesis" no hace más que enrarecer y prestar mayor confusión a un vocablo de por sí difícil y nada usual.

Creo que los testimonios aducidos son más que suficientes para hacer caer en la cuenta a cualquier lector inteligente, de que la redacción y el lenguaje utilizados no prestan precisamente fluidez y vivacidad al Catecismo. Es cierto que en ocasiones (como sucede en todas las facetas de la vida) hay que acudir inevitablemente a una terminología acuñada y precisa. No seré yo 
quien esté contra su empleo. Pero si de lo que se trata es de acertar en la manera de presentar la fe católica, no hay más remedio que dejar constancia de las muchas deficiencias, y de la enorme distancia entre el ideal a conseguir y el resultado que se ha puesto en las manos del lector de lengua castellana. Por eso tengo conciencia de no haber exagerado lo más mínimo al haber tenido ocasión de afirmar que se trata de un libro de lectura difícil. La claridad a la que aludían los miembros de la Comisión Editorial del Catecismo se les ha escapado entre los dedos.

\section{Otros aspectos formales.}

Junto a las cuestiones del lenguaje utilizado, y los cuestionables datos de la redacción efectuada en los ejemplos anteriores, hay, además, una serie de interrogantes que afectan principalmente a la forma, pero, como ha habido ocasión de comprobar, también tienen que ver con el fondo de las afirmaciones que se van desgranando en las páginas del Catecismo. Si se quiere, las que siguen a continuación tienen una importancia secundaria, si se las compara con algunas de las que han precedido en este estudio, pero en mi estimación no son tan triviales como para dejarlas pasar sin dejar constancia de ello, y no elevar la consiguiente lamentación por haber dejado malograr lo que pudo ser una oportunidad, y se ha quedado en poco más que una victoria pírrica.

He hecho alusión al relativamente abundante uso de expresiones que no figuran en castellano, siendo así que la totalidad podrían haberse traducido. No niego que en algún caso puede haber sido útil o aconsejable adjuntar el tecnicismo correspondiente al vocablo castellano al uso, para mayor precisión o afirmación de tal o cual matiz. Todos lo hemos hecho, y yo también. Pero lo que tendría que ser ocasional, y por lo mismo, excepcional, deviene en el Catecismo un defecto casi crónico, con una serie de agravantes, que voy a exponer.

Francamente no entiendo la insistencia, casi obsesiva, por incluir frases o palabras en latín, cuando el hacerlo no añade nada a la expresión castellana. Porque si se opta por presentar el texto en castellano, no hay por qué adobarlo con expresiones latinas estrictamente inútiles. Tal es el caso de las dos ocasiones que figuran en el n. 113, empezando por "Sacra Scriptura principalius est in corde Ecclesiae quam in materialibus instrumentis scripta", que luego se ofrece traducida; y después, a continuación de otro texto castellano igualmente traducido se pone la frase original latina ("secumdum spiritualem sensum quem Spiritus donat Ecclesiae"); lo mismo ocurre en el $\mathbf{n}$. 276, al hablar de "Dios todopoderoso y eterno" ("omnipotens sempiterne 
Deus"); vuelve a suceder en el número siguiente, el 277, a propósito de la misericordia divina ("Deus, qui omnipotentiam tuam parcendo maxime et miserando manifestas"); de nuevo aparece la inútil expresión bilingüe en el n. 385 ("Quaerebam unde malum et non erat exitus"); se repite el doblete en el n. 391, al citar al concilio de Letrán en relación con el demonio ("Diabolus enim et alii daemones a Deo quidem natura creati sunt boni, sed ipsi per se facti sunt mali"); otro tanto se encuentra, con ocasión de la doble realidad humana y divina de Jesús, en el n. 469 ("Id quod fuit remansit et quod non fuit assumpsit"). Se podrían seguir poniendo ejemplos de esto mismo; pero confieso paladinamente que me aburrí de ir tomando notas constantes de un defecto tan repetido, y que, precisamente por eso mismo, suscita la sospecha de si no habrá una intención no manifestada.

Esto mismo resulta aún más llamativo en los números 1.300 y 1.513 , relativos, respectivamente a los sacramentos de la confirmación y de la unción de enfermos, en los que se incluye la fórmula de la celebración en latín y en castellano. ¿Por qué?, ¿y por qué sólo en estos sacramentos y no en todos? ¿Están mejor celebrados en latín que en castellano?; ¿o acaso existe una corruptela en la fórmula castellana de estos sacramentos que obliga a duplicarla para evitar dudas sobre su validez? ${ }^{28}$.

El asunto se podría dar por zanjado (ya que no altera nada básico, y sólo contribuye a una engorrosa duplicidad), si no fuera porque en ocasiones adquiere otros tonos más serios y comprometedores. Se trata de las ocasiones en que el texto latino ha sido traducido, pero ha sido mal traducido, lo que, evidentemente, resulta más importante. Un ejemplo de ello se encuentra en el n. 817, a propósito de un texto de Orígenes, que se propone en la repetida forma bilingüe con estas palabras textuales: "Ubi peccata sunt, ibi est multitudo,ibi schismata, ibi haereses, ibi discussiones. Ubi autem virtus, ibi singularitas, ibi unio ex quo omnium credentium erat cor unum et anima una ('Donde hay pecados, allí hay desunión, cismas, herejías, discusiones. Pero donde hay virtud, allí hay unión de donde resultaba que todos los creyentes tenían un solo corazón y una sola alma')". Para quien sepa latín, no es un secreto que traducir "multitudo" por "desunión" no es proceder con el sentido más recto que se le puede dar. A ello hay que añadir que

28 Si en esta cuestión, como parece más seguro, se ha seguido un criterio aleatorio, o no se ha seguido ningún criterio previamente pensado, aún otro dato inexplicable, aunque no tenga que ver con el uso del bilingüismo. Se trata de que en el n. 1.300 se ofrece la doble fórmula de la confirmación para la liturgia occidental y para la liturgia oriental; lo mismo que sucede en el n. 1.240 , con ocasión del bautismo. Y de nuevo surge la pregunta: Si se han incluido ambas fórmulas en estos sacramentos, ¿qué razón hay para que no se haya hecho lo propio con el resto? 
la palabra "singularitas" se ha quedado sin traducir. Y lo curioso es precisamente que en la antítesis que Orígenes establece en los dos miembros de la frase, "singularitas" se está oponiendo a "multitudo". Flaco servicio ha prestado quien ha hecho la traducción, o quien ha aportado la consulta de la cita.

Ya indiqué antes la deficiente y probablemente más que intencionada traducción del n. 25 de Lumen Gentium, donde a la palabra "obsequium" se la fuerza hasta hacerla ser traducida por "obediencia" (n. 892).

En el n. 1.381 se incluye con la reiterada fórmula de utilizar el latín y además el castellano el poema eucarístico "Adoro te devote, latens Deitas". El último verso de la composición latina es "Nil hoc Veritatis verbo verius", y la versión castellana que se ofrece a continuación dice: "nada más verdadero que esta palabra de Verdad". Resulta patente que "Veritatis verbo" no es equivalente a "palabra de Verdad" (aunque se emplee la mayúscula), sino que es la "palabra de la Verdad" que es Jesús (Jn. 14,6).

No son las únicas ocasiones, ya que en otros casos, alguna expresión de los Santos Padres está materialmente bien traducida, pero extraída del contexto literario e histórico en el que fue escrita, por lo cual el sentido resulta forzado.

No terminan con esto los problemas derivados de la traducción, ya que aunque suele ser frecuente poner en dos idiomas el texto, esto no siempre sucede; no son infrecuentes las ocasiones en que -aunque puede parecer sorprendente- sólo figura el texto en latín, y se deja al lector que no lo conozca con un palmo de narices. Así el título que consta inmediatamente antes del n. 362 dice escuetamente: "Corpore et anima unus".

En el n. 875 aparece la expresión "in persona Christi Capitis", que no se traduce, ni tampoco va acompañada de la referencia correspondiente al documento de que procede. Hay que desplazarse al n. 1.548 (al que remite la referencia marginal), donde se vuelve a encontrar la misma expresión, está vez con referencias documentales, pero que permanece obstinadamente en latín. Ni en el n. 875 , ni en el n. 1.548 se remite al n. $1.348{ }^{29}$, en el cual vuelve a aparece la fórmula "in persona Christi capitis" (la última palabra, esta ocasión aparece con minúscula), pero tampoco se traduce. Parece lógico deducir que existe voluntad de declararla intraducible, aunque no se me alcanza el motivo de semejante decisión.

De todos es sabido (de todos los que conocen el latín) lo que significa "lectio divina"; los que desconocen este idioma seguirán igual que antes aun-

29 En este número, en referencia marginal, se remite al n. 1.548, pero no sucede lo propio a la inversa. 
que consulten el n. 1.177 del Catecismo. Y si no lo saben, lo pueden suponer, porque resulta muy fácil. Lo mismo ocurre con la palabra "character", que es el sello espiritual indeleble que ciertos sacramentos proporcionan a quien los recibe; ocurre que si en vez de "character" proporcionan únicamente "carácter", el sello espiritual tiene menos fuerza (ver el n. 1.272).

El sacramento del orden ofrece la oportunidad de hablar de una "ordinatio" que constituye a quien es designado dentro de un "ordo". No importa que no se entienda, ya que la expresión resulta muy exacta; tan exacta que se puede continuar afirmando que hay tres "ordines" (eso sí, se aclara que está dicho "en latín"), que son respectivamente "ordo episcoporum", "ordo presbyterorum" y "ordo diaconorum"; además se añade, a mayor abundamiento, que los "ordines" latinos tienen un equivalente en griego que se escribe "taxeis". Por si alguien no cree lo que estoy copiando, tómese la molestia de consultar el n. 1.537. Prácticamente complementario es el n. 1.554 donde se habla de "sacerdos", para designar usualmente uno de los tres "ordines" de que hablaba el anterior número 1.537. El "sacerdos" ya designado tiene que ofrecer, según el n. 1.553, el sacrificio "per ipsum et cum ipso et in ipso" (así consta, con minúsculas), en una unión entre "caput et membra". Que quede bien claro.

Como ello no reviste especiales problemas, se llega a extender el uso del latín sin traducir a aquellos textos que, según el n. 22 "tienen como finalidad ofrecer sugerencias para fórmulas sintéticas y memorizables en la catequesis de cada lugar". Se incluye, en consecuencia, el conjunto de las expresiones "munus docendi", "munus liturgicum" y "munus regendi" como sugerencia de fórmulas memorizables (ver el n. 1.592). Después de haber llegado hasta ahí, apenas existe dificultad para entender el significado de "ora et labora", de la regla de San Benito, y se deja en el idioma primitivo (en el n. 2.834 del Catecismo).

Pero los agobios no han concluido, porque aún quedan las expresiones griegas. Ya he presentado una muestra con el "taxeis" del sacerdocio. No es la única, porque hay que saber que el equivalente a la diócesis latina es la "eparquía" griega (n. 833); los católicos orientales son ungidos con "myron" al recibir la confirmación, y los católicos occidentales, si se descuidan, también, ya que los n. 1.289 y 1.297 hablan del "myron", además del "crisma", pero el n. 1.299 sólo habla del "myron". El n. 1.352 emplea la expresión "anáfora", a la que aludí antes, en el transcurso de la cual tienen lugar la "epíclesis" (n. 1.353) y la "anámnesis" (n. 1.354) ${ }^{30}$.

30 También pueden encontrarse estas expresiones no traducidas en los n. 1.103 y 1.105 (entre otros lugares), y todas ellas armoniosamente ligadas en el n. 1.106: "Junto con la Anam- 
Por su lado, el n. 1001 habla como un término inteligible para todo católico de la "Parusía" de Cristo; no creo yo que todos están seguros de su significado. Y como colofón, se nos recuerda que en Oriente existe el "Acathistós", junto con la "Paráclisis" y los "theotokia" (n. 2.678).

A este ya complicado laberinto idiomático, habría que añadir la frase en inglés de Juliana de Norwich (n. 313), que también incluye, sin explicación aparente, una palabra íntegra en letras mayúsculas "MANNER". Todavía podría sumarse algún otro dato a este batiburrillo idiomático, puesto que no consigo entender el empecinamiento en el uso de la palabra hebrea "Sabbat", en lugar de la castellana "sábado" (pero puede encontrarse en los n. $314,345,348$ y 1.166).

A la vista de lo anterior, me pregunto si el Catecismo puede tener como destinatarios a todos aquellos a los que, teóricamente, se dirige. Pero, de seguir manteniéndolo, habrá que ir pensando en la confección de un diccionario adjunto.

\section{La cuestión de los contenidos.}

$\mathrm{El}$ asunto resulta particularmente espinoso. Parece que mientras las críticas o el examen de una obra se quedan en aspectos formales, nadie se siente especialmente molesto. Todo lo más, "son mosquitos que zumban junto al que duerme...". Pero no intranquilizan a los responsables. Y acaso se hace una graciosa concesión parecida a "efectivamente, esto podría haberse dicho mejor", que viene a ser una ratificación: "pero en el fondo no está mal lo que se ha publicado".

Ya he indicado que las cuestiones de forma afectan también al fondo, y que entrañan una grave trivialización el considerarlas como algo secundario, marginal. Pero yendo directamente a las cuestiones de fondo, no hay más remedio que decir las cosas claras y directas. Y esto a propósito de dos manifestaciones. La primera es la del cardenal Ratzinger que afirma: "Lo único opinable y por lo tanto criticable son las formulaciones, la organización y la estructura del catecismo, pero no sus contenidos" ${ }^{31}$. La segunda, de Angel Suquía, un poco más extensa: "En este contexto, no puedo menos de lamentar las reticencias con que se ha recibido y hasta las críticas que se hace al Catecismo (de la Iglesia católica) desde algunas instancias eclesiales, especialmente en el ámbito teológico y catequético. La grave falta del sentido de

nesis, la Epiclesis es el centro de toda celebración sacramental, y muy particularmente de la Eucaristía".

31 "Vida Nueva", n 1.849, 4 julio 1992, 37. 
la comunión eclesial, a que acabo de referirme, se pone muy de manifiesto aquí. Por eso hay que decir que tales críticas, independientemente de la respuesta que haya que darles, también en el terreno estrictamente científico y teológico, no construyen la Iglesia, ni hacen progresar la teología: sólo sirven para debilitar la comunión eclesial, que es condición de toda evangelización fecunda" ${ }^{32}$.

Tales manifestaciones me producen una infinita pena. Es triste que la única postura deseada y esperada por parte de algunos responsables sea la de la alabanza, que, a lo que parece, fortalece la comunión eclesial. La más rancia y depurada reflexión eclesial ha visto en la Iglesia aciertos y fallos. Y ha dejado constancia de ambos para estimular los aciertos y obviar los fallos. ¿Cómo es posible decir que ejercer la función crítica mina el sentido eclesial? ¿Cómo se puede asegurar que los contenidos son intangibles, y no pueden ser examinados siquiera? Resulta penoso que el ideal eclesial haya que situarlo en un coro de aduladores inconscientes, de aplaudidores de oficio, de creyentes adocenados.

Manifiesto a los cuatro vientos mi voluntad decidida de ejercer el derecho a la crítica (para lo positivo y para lo negativo) desde dentro de la propia Iglesia, en plena comunión eclesial, queriendo y fomentando que haya cada vez más cristianos conscientes y responsables, que haya una presentación de la fe que se ajuste más y más a los dictados del evangelio de Jeşús de Nazaret y a necesidades y aspiraciones de los hombres. Y lamento y lamentaré todas las voces autoritarias que pretendan reducir la crítica al silencio, so capa de cerrar filas y fomentar la unión. ¿Para cuándo y para dónde, si no, hay que dejar la "libertad de los hijos de Dios” (Rm. 8, 21)? ¿Cuál es el terreno adecuado para examinar un Catecismo, si las conclusiones del examen han de permanecer en las catacumbas? ¿Se podrán aplicar al terreno eclesial las frases que Quevedo escribió pensando en el político:

"No he de callar, por más que con el dedo, ya tocando la boca, o ya la frente, silencio avises o amenaces miedo.

¿No ha de haber un espíritu valiente?

¿Siempre se ha de sentir lo que se dice?

¿Nunca se ha de decir lo que se siente?"

32 A. Suquia, Discurso ante la Conferencia Episcopal Española, 15 de febrero de 1993, en "Vida Nueva" n 1.882, 20 febrero 1993, 19. 
Por ello ejerzo, con apasionado deber y sentido eclesiales, mi derecho a criticar los contenidos del Catecismo de la Iglesia Católica.

En el terreno de las relaciones entre la fe y la razón (n. 35) o entre la fe y la ciencia (n. 159) nada habría que reprochar si no fuera por el hecho de la excesiva brevedad con que se aborda, frente a la amplitud y riqueza de la constitución conciliar Gaudium et Spes. Nada se dice de las difultades que se pueden plantear; se presenta con una cita del Vaticano I, carente de todo tipo de explicación, la simple supeditación del saber natural al saber sobrenatural, como si esto fuera un hecho indiscutible y universalmente aceptado; y cuando se acude al maravilloso texto de GS 36, se deja fuera de la cita lo mejor y más apasionante del texto, que presenta el legítimo sentido de la autonomía de las realidades temporales que "reclaman imperiosamente los hombres de nuestro tiempo" y que "responde a la voluntad del Creador". Es una verdadera lástima, y lo critico porque lo lamento; porque me hubiera gustado haberlo encontrado incorporado y asumido en el Catecismo, y no ha sido así.

Encuentro adecuado, y bien presentado, todo lo que se dice de la revelación en los n. 65-66, no así lo que aparece en el número 67. Se ha venido hablando de la Revelación progresiva de Dios a los hombres, que ha culminado en Jesús; a continuación (n. 67) se habla de las revelaciones "privadas", que no pertenecen al depósito de la fe, y no que sirven para "mejorarla" o "completarla" sino que su función es "la de ayudar a vivirla más plenamente en una cierta época de la historia". Si esto es verdad (aunque aparezca como datos complementarios, en letra pequeña), me gustaría saber qué razón existe para que no se haya aplicado plenamente este criterio a propósito de la devoción al sagrado Corazón de Jesús, que entra de lleno dentro de esta categoría de "revelaciones privadas"; y que, sin embargo, es tratado con categoría de dato importante para la fe, en letra grande, en el n. 478, donde no aparece estrictamente la palabra "devoción", con todas sus resonancias históricas, pero cuyos ecos son más que evidentes.

En el segundo párrafo del mismo n. 67 se produce un cambio de tono, que no se explica, cuando aparece la palabra revelaciones entrecomillada. Cualquier lector formado es capaz de entender que aquí "revelaciones" no se puede equiparar a las revelaciones privadas de que hablaba el párrafo anterior, sino a las supuestas, inventadas y subjetivas manifestaciones más o menos religiosas de ciertos líderes espirituales, que el Catecismo concreta en ciertas religiones no cristianas y también en ciertas sectas. Creo no deșbarrar al exigir que el cambio de acento debería haberse explicitado sin rodeos, puesto que no todos los lectores serán capaces de percibir el cambio de acento. Y lo mismo hay que decir al hecho de que las religiones no cristianas, así como el de las sectas, requieren diverso tratamiento. A propósito de las religiones no cristianas debería haberse 
matizado más, que mientras unas tienen un esquema de creencias perfectamente definido, y por tanto no son proclives a "revelaciones" libres, otras se prestan a la mera contemplación subjetiva y personalista del líder o fundador. Con respecto a las sectas, aun con toda la dificultad y complejidad del problema, también hubiera sido de desear algo más que media línea.

Hay en esta cuestión de los contenidos un apartado escabroso, especialmente al tener en cuenta a quienes piensan que lo que pretendo es desautorizar a los obispos, como maestros de la fe. Nada más lejos de mi intención. Ahora bien, ello no supone que haya que hipertrofiar la función docente de los obispos como la única forma adecuada de presentarla. A mí me parece que en el n. 87 se saca una conclusión que, si bien no es errónea, con arreglo a la lógica, tampoco es la única posible. El número en cuestión dice: "Los fieles, recordando la palabra de Cristo a sus apóstoles: 'El que a vosotros escucha a mí me escucha' (Lc. 10,16; cf LG 20), reciben con docilidad las enseñanzas y directrices que sus pastores les dan de diferentes formas". No seré yo, ciertamente, quien invite a la indocilidad o a la rebelión. Pero no creo que sea desafortunada la conclusión de que lo que Cristo quiso es asegurar su enseñanza más allá del límite de su vida terrena; y que si sus continuadores son directamente los apóstoles, estos, por su parte, confían esta misión y responsabilidad a sus colaboradores y a sus sucesores. Al menos ése es el sentido que se desarrolla a lo largo de Lumen Gentium 20. Una conclusión es que los cristianos se sienten vinculados por comunión de fe con quienes les transmiten la palabra de Jesús ("Eran constantes en la enseñanza de los apóstoles..." Lc. 2, 42). Otra conclusión posible es la preocupación por mantener viva y válida la legitimidad en las expresiones de la fe, que compete a los apóstoles y a sus sucesores. Otra conclusión sería la continuidad entre la cabeza y los miembros en la Iglesia, en la que siguen resonando las palabras de Jesús. También está presente, por supuesto, el agradecimiento de los miembros de la Iglesia a Cristo, así como a los demás intermediarios a través de los cuales se ha hecho posible su adhesión a la fe. Pero presentar como la única conclusión de los textos evangélico y conciliar la docilidad de los fieles hacia sus pastores, me parece abusivo por dos razones: porque el texto evangélico permite otras conclusiones igualmente legítimas; y porque el texto conciliar no lleva directamente a extraer la conclusión que aquí se propone. Acaso aparecen también aquí los resabios, a los que me referí con anterioridad, según los cuales se había manipulado en el n. 894, para que la traducción castellana que dice que los fieles deben adherirse a su obispo "con religioso respeto" se haya forzado en el Catecismo hasta hacerla decir que deben "adherirse... con espiritu de obediencia religiosa". Si los obispos sienten la necesidad de reclamar más atención por parte de los miembros de 
la Iglesia, o perciben que éstos les son indóciles, el camino más adecuado no es el de forzar textos conciliares para reforzar su misión. Con la advertencia, que no está de más recordar, de que lo que en definitiva se debe plantear es la fidelidad a Cristo y a su mensaje.

El n. 110 del Catecismo es impecable, y cualquier exégeta, catequista o responsable de cualquier forma en la presentación de la fe podrá estar plenamente de acuerdo con él sin dificultad, al afirmar que una de las claves para una correcta interpretación de la Biblia es conocer la intención de los autores, expresada por medio de los "géneros literarios". La sorpresa viene cuando se comprueba que esto no se lleva a la práctica en el Catecismo, y que se habla de seres individuales, singulares y concretos como seres históricos perfectamente documentados, como en el caso de Adán, Eva, Caín, Abel, Noe ${ }^{33}, \ldots$ a lo largo de numerosos lugares del Catecismo ¿Dónde está el género literario en estos casos? ¿O es que se trata de enunciar un principio inoperante? Por supuesto que en las explicaciones exegéticas de los géneros literarios nadie serio niega, sino que afirma con absoluta certeza, la verdad religiosa que tales narraciones contienen: Dios creador, el hombre libre capaz de volverle la espalda, Dios que quiere tender su mano salvadora... No acierto a comprender a qué hay que esperar para que estos logros adquiridos en la reflexión eclesial pasen a las páginas de un texto que se propone presentar actualizada la fe. El concilio Vaticano II no tuvo problema alguno en hacerlo suyo, y en el n. 110 se reproduce el texto de Dei Verbum, 12. Pero es obvio que a un concilio no le corresponde hacer una explicación de ello; cuando se escribe bastantes años después un Catecismo, que sí debería explicarlo autorizadamente, no lo hace. ¿A qué esperar, entonces?

Hay una frase que me parece absolutamente inexplicable, y que no acierto a entender cómo puede figurar en las páginas del Catecismo, si, como se dice, han funcionado tantos controles, filtros y revisiones en las redacciones sucesivas. Está situada a mitad del n. 1.250 que habla del bautismo de niños. Es la siguiente: "La pura gratuidad de la gracia de la salvación se manifiesta particularmente en el bautismo de los niños". Si se lee el número sin dicha frase, nada se pierde. Pero no se trata únicamente de una cuestión de redacción, sino de contenidos de fe. ¿Cómo es posible afirmar que la gra-

33 Resulta sorprendente, por ejemplo, la forma de omitir lo relativo a los géneros literarios que aparece en el n. 2.056, en que se dice: "La palabra 'Decálogo' signifićca literalmente 'diez palabras' (Ex. 34, 28; Dt 4,13; 10,4). Estas 'diez palabras' Dios las reveló a su pueblo en la montaña santa. Las escribió 'con su dedo' (Ex. 31, 18; Dt 5, 22), a diferencia de los otros preceptos escritos por Moisés..." ¿Para decir que son expresión de la voluntad de Dios, hace falta atenerse a la literalidad de que han sido escritas "con su dedo"? Pero esto, así de simple, no aparece en el Catecismo. 
tuidad de la salvación se percibe con mayor nitidez en el bautismo de niños? ¿No es siempre pura gratuidad de Dios? En el bautismo de niños, como en el de adultos, es Dios quien quiere tomar la iniciativa para hacer hijos suyos a los hombres. El que el adulto sea capaz de percibir conscientemente el hecho y el niño no lo sea, nada modifica la pura gratuidad de la gracia, con arreglo a los más acrisolados tratados de teología sacramental.

Entre los problemas pastorales que ha suscitado y sigue provocando el sacramento de la confirmación, está el asunto de qué edad es la más adecuada para su recepción, o, por mejor decir, cuáles son las condiciones idóneas en las que se debe impartir. El n. 1.306 del Catecismo presente las exigencias desde el punto de vista canónico, así como el n. 1.307, que se limita a hablar de "la edad del uso de la razón"; por su parte el n. 1.308 sale al paso de unas de las tendencias o corrientes pastorales que perfila al sacramento como "sacramento de la madurez cristiana", y lo hace poco menos que para desautorizarla, aunque en rigor no dé tal impresión. Nadie en su sano juicio discutirá la diferencia que existe entre madurez cristiana y madurez humana, como tampoco nadie en las mismas condiciones negará que la madurez cristiana suele ir acompasada con la humana, ya que el crecimiento en la fe no se improvisa, ni se hace al margen de las condiciones de la persona. Desde esa perspectiva, sorprende que el Catecismo manifieste en este n. 1.308 unas cautelas, dignas de ser tenidas en cuenta, al optar por la perspectiva de enfocarlo como sacramento de la madurez cristiana, y en cambio, no haga idéntico esfuerzo de señalar las cautelas que se deben tener cuando el sacramento se vincula literalmente a "la edad del uso de la razón", o cuando en función del criterio de "sacramento de iniciación" se celebra junto con el bautismo de niños, o muy poco después. Si es bueno -y es de agradecer-señalar cautelas, habrá que hacerlo para todas las opciones, y en todos los casos y no sólo para una opción. Y de hacerlo para todos los casos, el Catecismo entraría en una problemática pastoral de no sencilla resolución. Lo que no me parece válido es que se haga una advertencia respecto a una legítima opción pastoral, y no se proceda de la misma forma con las otras.

Respecto al ministro de la confirmación (asunto contemplado en los $n$. 1.312 y 1.313) a mi entender se hacen unos equilibrios innecesarios para tratar de armonizar, sin que exista contradición, las tradiciones oriental y occidental. El hecho de que sean dos tradiciones diversas invita a aceptar el hecho pluriforme: lo malo es que al pretender dar las razones que sustentan a una y otra tradición, se percibe con claridad que si son válidas las razones que sustentan un comportamiento, los motivos en favor del otro quedan relativizados. Curiosamente, ese despliegue de razones no se ha llevado a cabo a propósito de otra divergencia práctica entre oriente y occidente a 
propósito de los sacerdotes célibes o casados (n. 1.579-1.580): se ha elegido la vía de presentar el hecho como una opción aceptada tan válida como la rehusada. Y en este caso, el asunto ha quedado mucho mejor que a propósito de la confirmación, ya que los argumentos teológicos, bíblicos y canónicos no terminan por convencer.

En relación con la eucaristía, el n. 1.380 del Catecismo hace una cita expresa de la carta Dominicae cenae, de Juan Pablo II. El texto aducido no es precisamente afortunado, por la cosmovisión implicada en el mismo. Reproduzco el texto citado: "La Iglesia y el mundo tienen una gran necesidad del culto eucarístico. Jesús nos espera en este sacramento del amor. No escatimemos tiempo para ir a encontrarlo en la adoración, en la contemplación llena de fe y abierta a reparar las faltas graves y delitos del mundo. No cese nunca nuestra adoración". En la primera frase, si Iglesia y mundo son dos realidades distintas (no afirmo que sean opuestas, sino la Iglesia existe para llevar el mensaje de Jesús al mundo al que está destinada), es enteramente lógico que la Iglesia sienta necesidad de la eucaristía, ya que es la comunidad de creyentes en Jesús; pero no veo tan lógico que esta necesidad se haga extensible al mundo, que no es creyente en Jesús. Una deficiente cosmovisión de Gaudium et Spes de una Iglesia que se siente enviada al mundo, con el que comparte esperanzas y angustias, lleva en este caso a suprimir todas las barreras y poco menos que a identificar, en un afán idealizador, Iglesia con mundo. Pero al avanzar un poco más en la cita, un sentido que se da a la adoración eucarística es el de "reparar las faltas graves y delitos del mundo". ¿Y quien repara las faltas graves y los delitos de la Iglesia? La Iglesia es la comunidad de los salvados, que quedan a cubierto de faltas graves y delitos, en tanto que el mundo sí puede cometerlos. Quienes estaban hermanados en la misma necesidad de culto eucarístico, se encuentran distanciados por la capacidad diversa de cometer o no cometer pecados. Léase, por favor, GS 2, donde aparece el concepto conciliar de mundo; y léase LG 8, donde se manifiesta sin equívocos la doble condición de una Iglesia santa y necesitada de purificación ${ }^{34}$. Me parece que ambos son más expresivos que el texto aducido en el Catecismo.

¡Qué tristemente pobre resulta el n. 1.389! Se habla en el mismo de la obligación para los fieles de la asistencia a la misa dominical. Se emplea la expresión "la Iglesia obliga a los fieles". Y no se dice una palabra del convencimiento, mucho más fuerte que todas las obligaciones. Si esa fuese la línea a seguir, tendríamos católicos obligados, pero no católicos convencidos. Menos

34 Por cierto, no existe problema en citar este texto en el n. 827; no veo la razón de que aquí no se haga uso de él. 
mal que resulta posible disentir de este planteamiento, para buscar otro más coherente con la fe y más profundo en sus razones. (Esas razones tampoco aparecen en el n. 2.180, sino en los que le preceden inmediatamente, a los que el texto no remite en la numeración marginal, inexplicablemente).

Lo mismo sucede a propósito de la obligación de la confesión, donde prima la perspectiva de la obligación sobre la del convencimiento, si bien las razones que inducen al convencimiento aparecen dispersas en números anteriores que hablan de la voluntad misericordiosa de Dios ${ }^{35}$.

El n. 1.863 habla del pecado venial. A propósito del mismo incluye una frase que es materialmente exacta, pero gravemente incompleta. Viene afirmando que tal pecado "no nos hace contrarios a la voluntad y la amistad divinas", y continúa: "Es humanamente reparable con la gracia de Dios". El pecado, todo pecado, grave o leve, es humanamente reparable, porque todo pecado exige por principio la libre voluntad humana de conversión, sin la cual, no puede ser reparable; pero como el hombre es incapaz de salvarse y perdonarse a sí mismo, el pecado, todo pecado, grave o leve, exige como condición indispensable la gracia de Dios, dispuesto al perdón y a la misericordia. En cambio, afirmar esto del pecado leve, como se hace en el Catecis$m o$, y no hacerlo del pecado grave es una irresponsable inexactitud. Porque lo adecuado hubiera sido hacer esta afirmación para hablar de los requisitos indispensables para obtener el perdón, matizando después la facilidad o dificultad de obtener el perdón para cada clase de pecados.

Otro par de problemas reclaman ahora mi atención: el de los sacerdotes secularizados, y el de los matrimonios separados o divorciados. Sé que hay una postura más "prudente" que aconseja hablar de estos temas en voz baja o en grupos reducidos y controlados, para no tener problemas, porque hablar de estas cosas en voz alta es complicado y molesto. Voy a ser imprudente. Sé que se trata de dos problemas diversos, pero hay un aspecto que los aglutina en la forma en que han sido abordados en el Catecismo. Ambos aparecen brevemente, y en párrafos impresos en letra pequeña, y por lo tanto, como "exposiciones doctrinales complementarias" (n. 1.583 para los sacerdotes secularizados; n. 1.650-1.651 para los divorciados). Me llama poderosamente la atención esta forma de tratamiento ante problemas serios, cuando compruebo que los n. 920 y 921 están dedicados a los ermitaños y

35 En relación con este número 1.457 (y no 1.475, como figura por error), J. L. LARRABE señala en "Vida Nueva" n 1.879, 30 de enero de 1993, 4, una importante precisión: lo que el canon correspondiente dice es que resulta necesario confesarse antes de comulgar, si existe conciencia de pecados graves, a no ser que concurra un motivo grave y no haya oportunidad de confesarse; pero el Catecismo ha traducido "opportunitas" por "posibilidad" de confesarse, lo cual, no es ciertamente igual. 
constan en letra grande, y por lo tanto, con un carácter de afirmaciones importantes en el conjunto de la exposición orgánica de la fe cristiana. Sinceramente, y con el mayor respeto hacia los ermitaños, creo que ha habido un error de planteamiento. Ni siquiera el error dimana de una cuestión numérica para ponerse a hacer indagaciones sobre si son más los eremitas que los sacerdotes secularizados, o que éstos y los divorciados superan en conjunto a aquéllos. Pero una Iglesia Madre que se preocupa de sus hijos los ermitaños con tratamiento principal no puede negar la misma categoría a aquellos hijos suyos que se encuentran en cualquiera de estas otras dos situaciones.

A mayor abundamiento, de los sacerdotes secularizados lo que aparece impreso está en la línea de una perspectiva canónica, que precisa su status y sus obligaciones. Ni una palabra de aliento; ni una solidaridad a vivir la vida cristiana, impresa con la misma fuerza de carácter sacramental en el bautismo y la confirmación que el sacerdocio con el orden. Quiero con-dolerme con mis hermanos cristianos los sacerdotes secularizados, tan desplazados hacia la penumbra. No sucede lo mismo con los divorciados que contraen matrimonio civil, fuera del sentir de la Iglesia, que se siente vinculada con ellos (por cierto, muy bien y valientemente presentado) por la Palabra de Jesús. A los divorciados se les respalda para que no se sientan separados de la Iglesia, y a la comunidad inmediata se la urge para que manifieste hacia ellos una solicitud atenta (n. 1.651). No comprendo el diverso criterio seguido en uno y otro caso. Por lo que respecta a los divorciados, se deja ver, aunque sea con la utilización de la letra minúscula, la dificultad objetiva de compatibilizar su situación con la coherencia que dimana del seguimiento de Jesús. No se dicen cuáles pueden ser las dificultades subjetivas percibidas por estos cristianos. Pero, al menos hay un intento de aproximación, más válido que el tratamiento que se da a los sacerdotes secularizados.

A raíz de abordar temas relacionados con el orden, sorprende que se haya despachado por la vía autoritaria, con unas razones de tan escaso peso teológico, y con unos fundamentos bíblicos que en definitiva nada prueban, dos temas que están aún pendientes de ser examinados con seriedad. No quiero decir que no haya gente que no lo haya hecho ya. Y voces autorizadas han emitido su punto de vista. A lo que me refiero es que la que se presenta como postura oficial y universal de la Iglesia no ha querido escuchar esas razones y ha zanjado hasta la fecha ambas cuestiones con un carpetazo. Se trata de los temas del sacerdocio de hombres casados, y el acceso de la mujer al sacerdocio. El Catecismo "resuelve" estas cuestiones en los n. 1.577-1.580 aduciendo argumentos que suponen hechos aceptados por la tradición eclesial. No es capaz de admitir que los planteamientos en ambos casos estaban inevitablemente condicionados por unas circunstancias que han marcado 
que los hechos avanzaran en esa dirección. Más en particular, la cuestión del sacerdocio de hombres casados ha derivado por caminos diversos en oriente y en occidente; pero incluso en occidente es una mera decisión eclesial, no fundamentada en la Biblia (que constata precisamente todo lo contrario ${ }^{36}$ ), y que si la Iglesia la ha establecido como norma, igualmente puede modificar. Respecto al sacerdocio de la mujer, los datos bíblicos que la excluyeron, de hecho, tampoco implican la voluntad expresa de Dios, que si se ha manifestado positivamente respecto a los varones, nada ha dicho respecto a las mujeres. Deducir desde lo que no se ha dicho es arriesgado. Porque son numerosas las cuestiones en las que Jesús no ha dicho nada y ha dejado manos libres para que la Iglesia se organizara. De ahí que me parezca simplemente una afirmación escurridiza la del n. 1.577 según la cual "la Iglesia se reconoce vinculada por esta decisión del Señor". Por otra parte, hasta el teólogo más lerdo es sabedor de que se trata de una cuestión abierta, y que el Catecismo ha asumido una postura. Hubiera sido un bonito ejemplo de honestidad teológica y eclesial reconocer que también hay otras.

Hay una afirmación en las páginas del Catecismo, que resulta francamente increíble. Y si no fuera por la constatación de tenerla ante la vista, cabría la posibilidad de que se trata de una tomadura de pelo. Cuando aborda la cuestión del primer mandamiento, afirma que se puede pecar contra la fe (o contra la esperanza y la caridad). La afirmación a que me refiero aparece en el n. 2.088, y textualmente dice: "Hay diversas maneras de pecar contra la fe: la duda voluntaria (...); la duda involuntaria designa la vacilación en creer, la dificultad de superar las objeciones con respecto a la fe o también la ansiedad suscitada por la oscuridad de ésta". Yo me pregunto cómo es posible pecar involuntariamente. Increíble. Pero si esta afirmación resulta peregrina, cuando se explica resulta que para no pecar contra la fe no se puede vacilar en creer, no ha de haber dificultades en superar las objeciones sobre la fe, o no se puede tener ansiedad por la oscuridad que la misma fe suscita. $¿$ Ocurre, entonces, que quien vacila en creer, o sigue viendo honestamente pegas, o no termina de decidirse, está pecando? Y además de forma involuntaria. No resulta serio. Otra cosa muy distinta sería haber hablado de una conciencia culpable si tras la indecisión se agazapa la cómoda voluntad de no comprometerse; o si las razones para despejar una duda de fe son suficientemente convincentes, pero no se quiere dar el brazo a torcer; o si existe el deseo de no aceptar la fe, por la sospecha intuida de las exigencias que de ella dima-

36 Algunos han querido llegar a ver en estas constataciones bíblicas una obligación y una exigencia dimanante de la propia voluntad de Dios, sin pararse a considerar lo que supone de expresiones ligadas a un contexto cultural, y expresiones de un ideal. 
nan. Pero en cualquiera de esas o parecidas expresiones se percibe claramente que existe una voluntad de permanecer en la indecisión, o que existe la decisión de no dar el paso que se percibe con nitidez.

Lo menos que podría haberse dicho expresamente en el n. 2.266 sobre la pena de muerte, es que se trata de una cuestión opinable. Que hay una coherencia cristiana en quienes creen que es válido el recurso a este tipo de sanción, como también la hay en quienes se manifiestan contrarios a la pena de muerte. Es evidente que un Catecismo no ha de ser un foro para debatir los argumentos en pro o en contra de una conducta concreta. El texto trata de ser cauto, y matizar todos los requisitos que harían posible recurrir a la aplicación de la pena de muerte. No hubiera sido menos prudente si hubiera expuesto las fundamentadas razones que existen para su abolición. Pero puesto que ambas opiniones existen, y existen con fundamentos, creo que lo más adecuado hubiera sido afirmar que es una cuestión opinable, en la cual cada una ha de esforzarse no en encontrar argumentos con que silenciar a su oponente, sino en descubrir razones para ser consecuente con la enseñanza del evangelio.

En cuanto al texto materialmente escrito, resulta desconcertante con relación al tema de la masturbación (n. 2.352), no por falta de claridad, o porque haya que reprochar falta de comprensión o un tratamiento meramente legalista. Ni siquiera se me ocurre nada que objetar sobre la definición propuesta. Lo desconcertante radica en que en este mismo número, al querer hacer una aproximación hacia la práctica pastoral en orden a emitir un juicio lo más exacto posible sobre la masturbación, se habla de una serie de circunstancias "atenuantes", entre las cuales está "la fuerza de los hábitos contraídos". Pero he aquí que en el n. 1.865 se afirma que "el pecado crea una facilidad para el pecado. Engendra el vicio por la repetición de los actos”. Y aquí está el problema: ¿Qué criterio seguir cuando se trata de una circunstancia atenuante o agravante? ¿Cómo distinguir entre hábitos y vicios? Es claro que, cuando las cosas se leen inteligentemente, no existe la aparente contradicción que aquí apunto al contrastar ambos números. El problema lo percibo -y no sólo para la masturbación, ciertamente- cuando no se hace una lectura sensata, y con criterios de pura literalidad a lo impreso, se tiene en cuenta una afirmación y se desconoce la otra.

Porque con todo ello lo que me parece que queda muy claro es que la fe es algo vivo, y que por lo tanto hay que vivirlo. Lo cual no invalida el esfuerzo laudable, necesario, de formular y expresar la fe. Pero cuando se expresa mal, cuando la redacción es defectuosa, o cuando los mismos contenidos son discutibles, lo menos que se puede hacer es reconocerlo con humildad. Estos contenidos confusos que he señalado no deben llevar a la conclusión de que 
todo el Catecismo es igualmente confuso. Pero no se puede pasar por encima del tema como si no hubiera ningún defecto notable.

\section{Los aciertos del Catecismo.}

Como obra humana que es, el Catecismo no puede verse desprovisto de aciertos y de fallos. Hay que suponer de entrada voluntad de acierto por parte de aquellas personas que han participado en mayor o menor medida en su redacción. Y si siempre no lo han conseguido, es de justicia reconocer los méritos que la obra encierra.

Naturalmente, voy a ir enumerando aquellos que a mí me parecen tales, con todo lo que de subjetivo y personal tiene una visión concreta, como es la mía. A nadie trato de imponer mi punto de vista, y me limito a enumerar lo que yo entiendo que son aciertos. El acompañarlos de un comentario mayor o menor resultará útil o indispensable, según los casos. En tal comentario aparecerá igualmente que determinados aciertos no lo son plenamente, porque se encuentran empañados por algún matiz negativo o incompleto.

Aunque el esquema inicial, como punto de partida, sea el del deseo de conocer a Dios, en seguida se entra en la Revelación, como dato o conjunto de datos que Dios propone a la consideración del hombre. Pues bien, teniendo en cuenta esa perspectiva, me parece válido el hablar de las "vías" de acceso a Dios, como medios de acceso; se recuerda la terminología más clásica, con arreglo a la cual se las denominaba "pruebas" (n. 31 y 32), pero el Catecismo pone menos fuerza en su carácter probatorio, que en el de los caminos que se abren para el acceso a Dios.

Es estupendo que se hable expresamente de la libertad de la fe (n. 160), y no que se de por supuesta. Esto queda de alguna forma empañado, cuando en el uso de su libertad ante la fe, el hombre no termina de creer y se debate entre las dudas, pues, como vimos, la duda involuntaria está clasificada entre las conductas pecaminosas contra la fe (n. 2.088).

$\mathrm{Al}$ afirmar la unicidad de Dios, se recurre a una fórmula típica y exclusivamente cristiana como es la del reconocimiento de que Jesús es "el único Señor", término equivalente a Dios. Y así se dice expresamente. Lástima que no se haya remitido a Hch 2, 36; $\operatorname{Rm} 1,4 ; 1$ Co 12, 3 o Flp 2, 11. Y encuentro igualmente muy exacta y ajustada la otra afirmación complementaria de que aplicar el mismo calificativo de "Señor" al Espíritu Santo no implica contradicción alguna, ya que supone el explícito reconocimiento de su carácter divino.

$\mathrm{Al}$ exponer las afirmaciones del credo, se tiene el valor de no eludir la cuestión de la procedencia del Espíritu Santo del Padre y del Hijo ("Filio- 
que"), con el reconocimiento de que semejante término no figuraba inicialmente en el profesión de fe de Calcedonia, pero que no contradecía la misma fe. Y también es de loar el valiente reconocimiento de que esta cuestión fue en el pasado, y sigue siendo en el presente motivo de divergencia con los ortodoxos (n. 247). También hay que reconocer a este propósito el hecho de que entre ambas confesiones cristianas está casi conseguida la unidad (n. 838), aunque la comunión no sea plena (n. 1.399), lo que no impide que en ciertas circunstancias se pueda llegar a participar de la comunión sacramental.

Encuentro magnífico el n. 272 que habla de la aparente impotencia de Dios ante el problema del mal, que en nada empaña su capacidad creadora: Dios no se desentiende de la suerte de los hombres, aunque en ese número concretamente nada se diga la participación que el hombre tiene en el mismo mal con su libertad y su responsabilidad. Y este silencio empaña el número anterior; habría que remitir a los $n .160$ y 1.730 y ss. sobre la libertad del hombre y al n. 2.309 sobre la capacidad que el hombre tiene de contribuir al mal de sus semejantes.

El tema de la creación, en términos generales, está bien abordado en su conjunto (n. 282 y ss.); sin embargo hay una timidez rayando en el miedo cuando se elude sistemáticamente la palabra "evolución", y solamente se emplea el descafeinado término de "devenir" (n. 283). A estas alturas esto resulta inconcebible, y así el posible logro resulta envuelto en una prudencia que por demasiado tradicional empobrece el conjunto. No son los únicos lugares en que se aprecia esa ambivalencia, ya que se afirma sin rodeos lo bueno de la creación también en el n. 1.359, mientras que en otro lugar, que citaré más adelante entre los fallos, se deja caer una sospecha que me parece lamentable.

Es bueno el reconocimiento de que Dios no sólo crea, sino que cuida de las cosas creadas, y que además concede a los hombres participar en su providencia, en su cuidado de una forma responsable (n. 306-307). Esto es completamente distinto de una lectura que entendía que el "dominad la tierra" daba derecho para usar y abusar de ella.

No ha habido problema en afirmar la igualdad básica en dignidad del hombre y de la mujer (n. 369). Se trata de una afirmación bíblica que con demasiada frecuencia se había dejado de lado, a la par que se subrayaban otros muchos textos de la propia Biblia que "justificaban" la discriminación. Es una verdadera lástima que, por un problema de una redacción no suficientemente pensada, esto no se haya puesto de relieve en el n. 1.605 , en el que se parte de la afirmación inicial de la igualdad, pero luego se dice que Dios da a la mujer como "auxilio" para el hombre, en lo cual, aparece implí- 
cita una instrumentación no válida. ¿Qué hubiera costado afirmar que cada uno de ellos es ayuda para el otro?

Encuentro válido, rico y claro el n. 688 donde se proponen una amplia serie de manifestaciones de la presencia del Espíritu en la vida de la Iglesia.

El n. 828 aborda el dato de la canonización de los santos en la Iglesia; no lo hace tanto desde la perspectiva de que no haya error en semejantes declaraciones (como en otro tiempo se ha hecho), sino en la perspectiva de entroncar con la santidad que Dios nos quiere comunicar. Lo único que se podría objetar es que esta cuestión podría haber quedado relegada al tratamiento con letra pequeña.

La cuestión de la unidad rota en la Iglesia lleva al reconocimiento de otras comunidades y grupos cristianos como participantes de la misma fe y, además, explícitamente, "como medios de salvación cuya fuerza viene de la plenitud de gracia y verdad que Cristo ha confiado a la Iglesia católica" (n. 819). Esa claridad no aparece tan meridianamente expresada, sino recogida con muchas cautelas y reservas en los $\mathrm{n}$. 846-848, en los que se empieza hablando de la Iglesia como medio privilegiado de salvación, para hablar de los que sin culpa suya no conocen a Cristo y a su Iglesia, sin llegar a reconocer que son la inmensa mayoría quienes no tienen culpa de haber nacido y crecido en una situación de no catolicismo.

El tratar la cuestión de la participación de los laicos en las tareas de gobierno y en las decisiones de la Iglesia (n. 911), es bueno; predomina, sin embargo, la perspectiva canonista con más nitidez que la perspectiva bautismal, que en sana teología debería haberse presentado con carácter prioritario y fundante, pues la disciplina legal se limita a reconocer los hechos que la participación bautismal cimienta. Da la sensación de que la razón sacramental del bautismo es válida para hablar del apostolado (n. 900), y deja de serlo al entrar en las decisiones de gobierno.

Me parece estupendo el repetido intento que figura a lo largo de la exposición del credo de vincular las diversas afirmaciones con la actuación de la Trinidad. Frente a unas formas de expresión usuales que se refieren a Cristo, este otro paso supone un acierto que no contradice lo anterior. Una bonita muestra de ello se encuentra en el n. 989 a afirmar que "nuestra resurrección será obra de la Santísima Trinidad"; ciertamente no es el único ejemplo.

En la misma línea resulta muy válido el reconocimiento de que la revelación del hecho de la resurrección ha sido progresivo (n. 992). Ahora bien, no me gusta en el mismo número el empleo de la palabra "pruebas", porque puede ser interpretado como "pruebas de la resurrección" que aducen los Macabeos en sus respectivas confesiones, cuando en realidad quiere decir 
"tormentos". También es asumida sin temores esta perspectiva de revelación progresiva a propósito del matrimonio, para ir estableciendo lentamente las condiciones de unidad e indisolubilidad (n. 1.610). No es un mal logro el plantear así las cosas.

Resulta muy válida la afirmación que, en consonancia con la resurrección, asegura que puesto que ésta entraña un revivir corporal, de ahí arranca una "exigencia de respeto hacia el propio cuerpo, y también hacia el ajeno" (n. 1.004). Es una consideración del respeto que merece todo el ser humano, alma y cuerpo; en buena lógica, hubiera sido bueno hacer extensiva la actitud de respeto a la parte psíquica del ser humano. $\mathrm{Y}$ aunque se ha dicho unos cuantos números antes (n. 999-1.000) que desconocemos detalles concretos en torno a la resurrección, sin embargo cabe la posibilidad de que alguien malentienda que el respeto a este cuerpo concreto (no tenemos otro) implique que hemos de resucitar exactamente como somos.

Pasando al apartado dedicado a la liturgia, se arranca de la idea que de la liturgia constituye la actualización de la historia salvífica de Dios. En los n. 1.079-1.081, compendiada, se presenta la historia de la salvación como la historia de la bendición divina, la historia de un Dios que bendice (que dice bien, que proclama que son buenos) los seres vivos. Resulta magnífico.

El criterio que señala el n. 1.126 es sumamente valioso, puesto que contempla la oración litúrgica como la expresión de la fe que se tiene y confiesa. En rigurosa consecuencia, si los cristianos de los diversos grupos compartimos la fe, aunque no sea plenamente, debemos compartir la oración litúrgica y la celebración sacramental como uno de los caminos más válidos para caminar hacia la mutua unidad. Con este punto se puede conectar perfectamente la afirmación del n. 1.271 que reconoce en el bautismo un punto de contacto sólido en orden a la unidad para la casi totalidad de las iglesias y grupos que se denominan cristianos. No es un dato que haya que despreciar ni pasar por alto con excesiva ligereza, ya que constituye uno de los pilares del diálogo ecuménico

El n. 1.180 recoge el trasfondo de identificación y simpatía entre la Iglesia viva, constituída por las piedras vivas de los cristianos (1Pe 2,5) y el templo material. Es válido pasar del contenido al continente, sin despreciar éste. Además se hace una alusión, si bien implícita, a la mentalidad protestante respecto del templo, cuando se afirma que "estas iglesias visibles no son simples lugares de reunión, sino que significan y manifiestan a la Iglesia que vive en ese lugar". No se hubiera perdido nada si semejante alusión ímplícita hubiera sido abierta y explícita, señalando así una ligera pero perceptible diferencia en el comportamiento de ambos grupos cristianos.

Creo que constituye un verdadero acierto la formulación del n. 1.455, en el cual no se induce a confusión alguna entre el sacramento de la penitencia 
y el psicoanálisis, pero no existe temor alguno en señalar, entre las razones que sostienen la práctica de la confesión, la manifestación de los pecados como sustentada en un motivo psicológico (el reconocimiento expreso y oral del propio pecado), así como en un motivo social (la aceptación abierta del mal causado a otros).

Denso, que no difícil, es el n. 1.501. En el mismo se afronta decididamente la compleja situación que la enfermedad desencadena, con sus imprevisibles y múltiples reacciones. El afirmar que la enfermedad "puede también hacer a la persona más madura" es un innegable logro, en un intento de tomar en serio lo humano para llegar en debidas condiciones a hablar del sacramento de la unción de enfermos.

El n. 1.550 me parece excelente. El lenguaje es claro, directo, sin rodeos. $\mathrm{Va}$ al grano y deja las cosas muy bien matizadas. La eficacia del sacramento no está condicionada a la persona que lo realiza; pero no se deja de reconocer que la intervención de los hombres concretos hace que el signo sacramental sea mejor o peor presentado o ejecutado, según las cualidades del ministro. Una llamada de atención valiente, oportuna y responsable.

En la presentación del matrimonio hay una frase de una frescura y una capacidad de sugerencia encantadoras, cuando asegura (n. 1.604) que el mutuo "amor es bueno, muy bueno a los ojos del Creador". Por desgracia, algo tan bonito y tan acertadamente expresado se malogra en el número siguiente, en el cual, como ya señalé, aparece la idea de la mujer como "auxilio" del varón, en lugar del auxilio y ayuda mutuos.

También en el tema matrimonial hay un par de aciertos notables, al hacerse eco de las dificultades que existen realmente para acceder al compromiso matrimonial. Para muchos jóvenes de nuestras sociedades europeas el obstáculo radica en el miedo a asumir un compromiso estable y de por vida (n. 1.648; ver también 2.390), mientras que para muchos catecúmenos, procedentes sobre todo del mundo africano, el impediento más notable es la situación de poligamia de la que culturalmente proceden (n. 2.387). A nadie se le oculta que lo complejo es dar con la respuesta eficaz y válida en cada caso.

Resulta curioso que tenga que ser la Iglesia la que propugne el valor de la fecundidad matrimonial en un mundo egoísta e insolidario que propone el placer en materia sexual como el único logro que merece la pena. Aunque el tema del placer sexual no siempre esté bien presentado, pues se vincula absoluta e inseparablemente a la fecundidad (n. 2.351 y 2.363), como si no fuera un bien en sí mismo en el transcurso del amor conyugal, un lazo de fortalecimiento afectivo y sentimental, lo que resulta obvio es que un planteamiento matrimonial que se cierre, por principio, a la procreación adolece de un serio defecto de partida. De ahí que encuentre valiosos los n. 1.652-1.654. 
Literalmente, no es exacta la expresión del n. 1.733 que dice sobre la libertad: "No hay verdadera libertad sino en el servicio del bien y de la justicia". Es claro que lo que se quiere decir con la palabra "verdadera" es equivalente a "buena" o "aceptable", emitiendo un determinado juicio de valor. No se trata de afirmar que la elección hacia el mal no es verdadera, o que no entraña responsabilidad. Esta deficiente expresión no empaña la verdadera calidad que se encuentra sobre todo en el n. 1.738, igualmente sobre la libertad, y el derecho a ejercerla, como algo inalienable.

El conjunto de los n. 1.846-1.848, con la denominación común de "la misericordia y el pecado", me parecen que están perfectamente redactados. Aun reconociendo que es un teina que se presta a ello, y que la riqueza de reflexión tanto bíblica como patrística es notable, el conjunto de esos números presenta con justeza lo esencial del tema, en el que únicamente echo de menos alguna referencia al Antiguo Testamento.

Estimo un verdadero acierto que se recoja, no por mera estrategia, la sensibilidad de que los derechos fundamentales de la persona han de ser salvaguardados. Y que el Catecismo los mencione explícitamente, llegando a afirmar que están insertos en la formulación del Decálogo, pues son inherentes a la persona (n. 2.070; además, n. 1.901, 1.930, el ya aludido 1.738). Frente a algunas formas de pensar que ponían el grito en las nubes ante una Iglesia que era sensible a la Declaración de los derechos humanos, y que la contraponía a los Mandamientos, llegar a hacer compatible la armonización de ambos datos es un motivo de justa satisfacción.

En el n. 1.931 hay un motivo de acierto al propugnar que, en materia social, o en cualquier otra materia, la legislación, por muy aquilatada que resulte, no suple los valores fraternales, con lo que invita a un comportamiento que más allá de las exigencias estrictamente legales, se plantee en términos cristianos con arreglo a los dictados de la ley suprema del amor ${ }^{37}$.

Me parece laudable sin ningún tipo de reservas el explícito rechazo que se hace de la violencia en los espectáculos multitudinarios (n. 2.187), plaga reciente, que no es privativa, por desgracia, de uno u otro continente.

Especialmente destacable es la prevención de la violencia u opresión contra los más débiles, como son los hijos, cuando se afirma en forma rotunda que los hijos no son cosas poseídas por los padres, con derecho a hacer con ellos lo que les parezca oportuno (n. 2.222).

37 Resulta notable la profunda identidad, no tanto en la terminología utilizada, cuanto en el pensamiento expresado, con la afirmación que hace el Catecismo holandés, Barcelona, Herder, 1969, 414: "Porque amor, en economía, es más justa distribución". 
También con arreglo a la sensibilidad actual, y la urgencia del problema, muestro mi acuerdo con suscitar el problema del hambre en el mundo como un asunto de justicia, que vulnera el quinto mandamiento (n. 2.269). La lástima es que el tema no haya sido abordado en toda su crudeza moral, ya que se habla con un término demasiado genérico de "la aceptación de la sociedad", y se señala directamente como responsables a los traficantes y comerciantes, mientras que no se dice una palabra de los gobiernos y poderes públicos ${ }^{38}$.

Creo que el n. 2.243 acerca de las condiciones válidas sobre la resistencia legítima a la autoridad constituída es modelo de claridad expositiva. Si el resto del Catecismo hubiera tenido la gallardía de seguir este estilo, otro gallo hubiera cantado. Además, en un problema serio de conciencia moral, se matizan una serie de presupuestos que la prudencia ha de juzgar si se cumplen o no ante una violencia tiránica. ¿Por qué no hablar con la misma claridad en otra serie de problemas morales?

También es claro, directo y franco el n. 2.285 al hablar de la especial gravedad que reviste el escándalo provocado por la autoridad, por la postura que cabría esperar por parte de quienes la ejercen.

El tema de la no violencia era uno de los que hasta ahora se había ido suscitando y desenvolviendo al margen de la Iglesia, como si ésta no se sintiera afectada por tan seria demanda. Que nadie entienda que la Iglesia no ha hablado ni hecho su aportación a la paz; se ha pasado de una Iglesia beligerante y poderosa a una Iglesia que ha sido y sigue siendo convencida luchadora por la paz. Pero el tema de la no violencia no había entrado con carta de naturaleza y reconocimiento expreso en un catecismo, aunque sí estaba presente en la reflexión conciliar (GS 78). Ahora, en cambio, se ha hecho semejante reconocimiento en el n. 2.306 del Catecismo. Con esto empalma, por su evidente vinculación, la cuestión de la objeción de conciencia, abordada en el n. 2.311, reclamando para ellos no un trato de favor, sino la justa atención de las autoridades.

Hay que aceptar sin reservas los n. 2.357 y 2.358 en los que se trata el asunto de la homosexualidad, con sus complejas y profundas implicaciones, que obligan a ser cautos antes que proceder a una condena apriorística. El

38 El tema aparece, además, en letra pequeña, como una cuestión de carácter "complementario". En el conjunto del Catecismo, es la única ocasión en que se aborda directamente. Aparece en otros dos momentos (n. 2.831 y 2.835) como un compromiso surgido de la oración del padrenuestro, al pedir el pan cotidiano. El resto de las ocasiones que se menciona la palabra "hambre" el hilo conductor de cada número correspondiente no lleva a hacer un riguroso planteamiento de justicia. 
planteamiento vinculante que se encuentra en la Palabra de Dios, lleva, quizá, a emitir un juicio de rechazo explícito de tal situación; semejante juicio está matizado en el n. 2.358 con criterios de una indispensable prudencia pastoral bien marcados, tanto personal como socialmente. Me parece que con ello se ha dado un paso no definitivo, pero sí significativo de una voluntad de comprensión.

El respeto a la integridad de la creación, en sus diversas manifestaciones, es, sin duda alguna, otro de los aciertos del Catecismo. No se trata únicamente de responder acomodaticiamente a una demanda social universal. Es, con lenguaje eclesial, uno de los signos de los tiempos que han ayudado a formular decididamente una afirmación que se encuentra en el libro del Génesis, pero que frecuentemente había quedado demasiado solapada con la afirmación del dominio del hombre sobre la naturaleza sometida a él. El dominio tiene que ser diferenciado del abuso incontrolado. Y es bueno que el Catecismo lo asuma sin paliativos (n. 2.415-2.428).

$\mathrm{Si}$ el resto de la creación merece un respeto, al considerarla obra de Dios, los seres humanos lo reclaman especialmente, tanto en el caso de que se hagan valedores de sus derechos y reclamaciones, como en el de aquellos que quedan poco menos que reducidos al silencio. El reconocimiento de este hecho y la postura decidida por parte del Catecismo, por ejemplo en el caso de los emigrantes (n. 2.433) me parece un acierto no discutible. Tan sólo echo de menos que en esta nueva formulación de los tradicionales "pobres" que aparecen en las páginas de la Biblia (la viuda, el huérfano, el forastero), no se haya hecho una expresa referencia a tan rico fundamento bíblico. En la misma línea se ha de leer el n. 2.448, que si bien comparto, tiene el fallo de presentación de una cita prolongada; ésta podría haberse abreviado para dar cabida a diversas categorías de "nuevos pobres" que produce un mundo cruel en exceso: asalariados por sueldos ínfimos, niños explotados, prostitutas, refugiados, analfabetos, disminuídos físicos o psíquicos,... El fondo de lo presentado no hubiera desmerecido, ni hubiera perdido altura, y hubiera ganado en fuerza expositiva.

Encuentro válido y razonado el n. 2.487 que contempla la exigencia de justicia de reparación de las faltas cometidas contra la verdad, de cualquier forma que se produzcan. Me parece que se podría haber tomado como modelo para haber hecho lo mismo en el n. 2.412 sobre las faltas producidas contra los bienes ajenos, y la exigencia de reparación, que está tratada más pobre y brevemente.

Al tocar la cuestión de la pureza, el Catecismo no se limita a hacer una formulación teórica, sino que se para a hablar de los medios prácticos (no 
utilitaristas) a través de los cuales se puede conseguir secundando la gracia divina (n. 2.519-2.520). Una llamada al realismo tiene que ser bien recibida.

Me parece laudable la definición que el n. 2.609 propone de la fe, que tiene muchos más visos de definición en términos bíblicos, vitales y humanos, que los términos abstractos, teológico-filosóficos y desencarnados de muchas definiciones al uso ${ }^{39}$. En términos breves y claros se incluye la adhesión confiada del hombre, la aceptación hasta de aquello que no entiende, la razón definitiva apoyada en la propuesta de Jesús de Nazaret, así como la vinculación filial que origina.

Es muy bonito el n. 2.735 que se hace eco de una preocupación ampliamente sentida: la eficacia de la oración, cuando ésta pretende pedir para nuestro beneficio; en ese número se plantea sin rodeos una solapada intención egoísta del orante, preocupado por la eficacia de sus súplicas, mientras no le preocupa tanto si otras formas de oración como las de alabanza o adoración resultan formas válidas o aceptables a Dios. Constituye, sin duda, un precioso aldabonazo a una oración más confiada y menos interesada.

La enumeración que he ido realizando de datos que me han parecido positivos en las páginas del Catecismo podría prolongarse aún más. Si ha sido bastante extensa es porque obedece a una voluntad de querer ver las cosas como son, sin prejuicios condicionadores de tener que poner mala cara a todo lo que aparece incluído en sus páginas. Y son bastante los aspectos en que, en mayor o menor medida, yo no tengo ningún inconveniente serio en reconocer que se trata de aciertos de fondo o de forma.

Es claro que otras personas podrían haber hecho otra selección, según criterios no exactamente iguales. Creo, en verdad, que no pocos podrán coincidir, si no en todos, al menos en gran parte de ellos. Y que ello se puede elevar a categoría de conclusión, al reconocer paladinamente que el Catecismo de la Iglesia Católica tiene aciertos.

Es igualmente claro, que también tiene fallos. Y con la misma libertad, y el mismo aprecio a la verdad de las cosas, reconozco lo uno y lo otro.

\section{Los fallos del catecismo.}

La enumeración de los fallos es tan larga o más que la de los aciertos. Procede, en consecuencia, que no me extienda demasiado en la consideración de cada uno de ellos, si bien el nivel de tratamiento no tenga que reves-

39 Puede compararse con la definición de fe más ajustada a los patrones de la reflexión teológica escolástica, que figura en el n. 1.814, para comprobar la diferencia con el frescor de la comentada aquí, de hondo sabor bíblico. 
tir en todos los casos la misma extensión, y en algunos sea forzoso hacer un comentario más amplio. En el resto de las ocasiones, dejo al buen criterio de los lectores el hacer sus propias reflexiones y deducir las consecuencias.

Algunos de esos fallos ya los he constatado en las páginas anteriores a propósito de cuestiones notables de contenido, fallos redaccionales, problemas de traducción o de alteración de textos. No he sido sistemático para detectar todos y cada uno, porque es seguro que podrían haberse puesto más ejemplos de propuestas problématicas, en mayor o menor medida. Los fallos que voy a enumerar ahora no los he incluído en las catalogaciones anteriores, salvo algún caso, en que me limito sencillamente a recordarlo.

Resultaría casi innecesario tener que advertir que mi intención no es la de atacar o demoler el Catecismo, sino examinar, ver, y manifestar mis puntos de vista. Como ocurría con los aciertos, los aspectos negativos pueden o no ser compartidos. Y también me parece obvio que tan parcial puede resultar la lectura que pretenda ensalzar el Catecismo, al comprobar sólo sus logros, como la que busque devaluarlo, fijándose únicamente en sus deméritos. Precisamente por ello he realizado un examen de ambas realidades.

El desacierto más importante, y más desafortunado es el inaceptable empleo de la Palabra de Dios que se lleva a cabo en numerosas ocasiones. En las páginas del Catecismo aparece con frecuencia una proposición, en letra grande, que después se trata de justificar mediante el empleo de la letra pequeña en la que, según el n. 20, presentan las "explicaciones complementarias". Pues bien, en esas explicaciones complementarias aparece la Palabra de Dios, que viene a corroborar la proposición previamente ofrecida. El que la Palabra de Dios no tenga el tratamiento de fuente de la que arranca y parte el pensamiento cristiano, sino que se relegue a la categoría de argumento de autoridad que viene a reforzar un pensamiento eclesial, de la índole que sea, no puede ser compartido ni en la teoría,ni en la práctica. La más rancia reflexión catequética y pastoral afirma esto con una rotundidad y con una seguridad que no se presta a dudas. Y si la reflexión catequética había madurado lo bastante como para que esto fuera un verdadero logro irrenunciable en los años inmediatamente precedentes al Vaticano II, la fuerza de la toma de conciencia eclesial parecía dar por sentado que esto adquiría carta de naturaleza indiscutible, salvo alguna excepción que, por eso mismo, tenía marcada una impronta de pobreza catequética.

Pues bien, eso que parecía que no podía ocurrir, ha ocurrido, por desgracia, en el Catecismo. Voy a poner un ejemplo, que reproduzco literalmente y que consta en el n. 991 : 
"Creer en la resurrección de los muertos ha sido desde sus comienzos un elemento esencial de la fe cristiana. 'La resurrección de los muertos es esperanza de los cristianos; somos cristianos por creer en ella' (Tertuliano, res. 1.1):

¿Cómo andan diciendo algunos entre vosotros que no hay resurrección de muertos? Si no hay resurrección de muertos, tampoco Cristo resucitó. $Y$ si no resucitó Cristo, vana es nuestra predicación, vana también nuestra fe...;Pero no! Cristo resucitó de entre los muertos como primicia de los que durmieron (1 Co 15, 12-14.20)".

La frase primera, podría haber sido mera introducción para la lectura de la Palabra de Dios, que -repito- es fuente de fe; resulta inaceptable que el texto de Tertuliano tenga un tratamiento prioritario, cuando resulta que Tertuliano, como cristiano, se limita a hacer una expresión de su fe, a partir de la Palabra de Dios que la ha nutrido. Dejar para el tratamiento secundario de texto complementario la misma Palabra de Dios es invertir los términos, presentándolos justo al reves de como debería haberse hecho.

Bastante lamentable es el hecho en sí, que no debería haberse producido. Lo grave es que esto no es fruto de una simple equivocación. Esto sucede, a lo largo de las páginas del Catecismo, no menos de dos docenas de veces. Para que nadie suponga que empleo un tono catastrófico a fin de exagerar un defecto, doy con profunda pena la larga lista de números en los que he encontrado repetido semejante despropósito: 989, 991, 1.046, 1.047, 1.227, $1.288^{40}, 1.439,1.781,1.816^{41}, 1.825,1.949,1.987,1.992,1.995,1.999,2.004$, $2.055,2.218,2.260,2.270,2.361,2.445,2.447$, y 2.606, salvo error u omisión. Creo que esto no es lo adecuado. Y que los responsables de la redacción deberían entonar el "mea culpa".

Me parece también que el n. 40 que aborda la limitación del lenguaje humano para hablar de Dios, y sus forzosas restricciones hubiera merecido un tratamiento algo más amplio que las tres líneas y media que se le dedican.

El tandem formado por los números 122 y 132 hubiera sido una oportunidad, desaprovechada, de mostrar las coincidencias básicas de los católicos con los judíos y con los protestantes en el uso y aprecio de la Biblia, tanto en el Antiguo como en el Nuevo Testamento.

40 En este número, que tiene el carácter expositivo del desarrollo normal del Catecismo, no se incurre literalmente en ese defecto. Si lo he incluído en esta lista es porque la situación es equiparable. En él se hace únicamente referencia al texto de Hch 8, 15-17. Y luego, con sorpresa, este texto que no ha sido reproducido aparece tal cual en el n. 1.315 que tiene la calificación de "resumen": no aparece la fuente en su debido momento, y se la reproduce en otro momento, con otra categoría en el tratamiento oficialmente propuesto.

41 Algo parecido sucede en este número, en el que tampoco se recurre al empleo de la letra pequeña, pero en el curso del cual se hacen una serie de afirmaciones sobre la necesidad de testimoniar la fe, poniendo en primer lugar una cita conciliar de LG 42, y después, como ratificación, el texto de Mt 10, 32-33. 
En el conjunto de los números $172-175$ se produce, a mi modo de ver, un exceso de citas de Ireneo de Lyon. Se trata de presentar la unidad compartida en la misma fe común; junto a textos de Ireneo, podría haberse mostrado alguna otra muestra de la abundancia de reflexiones sobre el tema, ya que los conatos de división han ocupado a muchos escritos eclesiásticos.

La radical profesión de fe monoteísta está recogida en el n. 199. También ahí, a mi modo de ver, se ha perdido una oportunidad de afirmar tanto las raíces del convencimiento monoteísta procedentes del judaísmo, como el hecho de compartir el mismo convencimiento con el islam, las tres grandes religiones monoteístas.

Al comienzo de la explicación del relato de la caída, como ocurre también en el la creación, y en el conjunto de los once primeros capítulos del Génesis, debería haberse atrevido el Catecismo a utilizar sin miedo la palabra "mito religioso". Eso para nada hace peligrar el fondo religioso y las afirmaciones de fe contenidas en la narración, pero el mero hecho de querer presentar como hechos históricos comprobados lo que no pasan de ser unas narraciones en las que se ensaya una respuesta a las preguntas sobre el origen del mundo y del hombre, resulta un esfuerzo destinado al fracaso. Eso se percibe a partir del n. 282, en toda la parte dedicada a la creación, en que se habla en general del "hombre". Pero después se cambia el estilo para pasar a hablar de Adán y Eva como unos seres humanos concretos, y perfectamente diferenciados por ser los primeros de todos (n. 399, 401, 404, 416); lo mismo sucede con Caín y Abel (n. 401, 2.259); y, cambiando la naturaleza específica, algo similar se podría decir de los ángeles, cuando se trata de su creación o de su caída. Siendo tan escaso lo que conocemos de ellos como materia segura de fe, me parece que se da una tratamiento excesivo y muy amplio a la cuestión de la caída de los ángeles, donde se entremezclan datos seguros con otros que no pasan de ser una suposición verosímil. Haber sido más escuetos y más ceñidos a lo verdaderamente fundamental hubiera sido una medida de sana prudencia.

En la parte dedicada a explicar la doctrina sobre Jesús, desde el n. 430 al n. 451 se consagran a ir comentando los títulos o nombres de "Jesús", "Cristo", "Hijo" y "Señor". Con toda la riqueza que ello supone, creo que podría haberse hecho más concisa la presentación, sin que ello hubiera supuesto merma notable. El exceso, como en este caso, constituye un defecto.

Algo semejante sucede en las explicaciones que justifican la conveniencia de la encarnación de Jesús (n. 457-460), que podrían haberse enumerado y explicado con brevedad y rigor. Que es precisamente lo que ha hecho el n. 456: en lugar de seguir este ejemplo, el exceso de explicaciones, con acumulación de citas, no beneficia la claridad. 
Los n. 632-633 se hacen eco de una creencia que está reflejada en el Nuevo Testamento y que supone una actividad ultramortal de Jesús. Esto debería haber quedado suficientemente claro si se pretende dar una explicación actualizada de la fe.

Entiendo que habría que haber sido mucho más sobrios a la hora de hablar del final de los tiempos, ya que las certezas en este punto son mínimas. ¿Por qué tratar de poner como afirmaciones de fe lo que no pasan de meras exposiciones complementarias del género literario apocalíptico, en que están redactados esos pasajes neotestamentarios? (ver n. 675 y 677).

Cualquier lector inteligente puede observar que se ha cometido un salto en el vacío y un error imperdonable al interpretar abusivamente la Biblia. El n. 710 viene hablando del exilio del pueblo de Israel, y justifica que "era necesario que el Pueblo de Dios sufriese esta purificación": para ello remite a Lc. 24, 26, que textualmente dice: “¿No era necesario que el Cristo padeciera eso para entrar así en su gloria?". Se hace una injustificada trasposición entre el Mesías y el pueblo de Israel, y se aplica a uno lo que el texto señala del otro, como razón justificativa de lo escrito. Sencillamente, no, por un mínimo de honradez.

El n. 766 acude a una interpretación de índole espiritual y alegórica, cuando habla de que la Iglesia surge del costado de Cristo, de la misma manera que Eva surge del costado de Adán. El texto conciliar citado sí hace referencia al primer miembro de la frase (aquí se usan bien las comillas). Pero el segundo miembro de la frase (aunque sea con punto seguido) establece una comparación que corresponde a una piadosa reflexión de San Ambrosio, que no constituye ningún dato esencial de la fe ${ }^{42}$.

El texto de Orígenes que aparece reproducido en el n. 817 ya lo comenté como un ejemplo de deficiente traducción. Pero es que además el texto es desafortunado, porque la idea que sugiere no es la que primitivamente trata de comunicar. En su contexto, Orígenes contrapone la Iglesia a los diversos grupos cismáticos y heréticos que minan e imposibilitan la unidad. En cambio, tal como está aducido en el Catecismo, da la sensación de que la Iglesia es el compendio de todo lo bueno, mientras que más allá de ella se concentra la maldad. Y esto no es cierto. La Iglesia no puede sentirse libre de culpas y responsabilidades tanto en las rupturas de la unidad, como en los errores y

42 Por cierto, la referencia de la cita de San Ambrosio está mal, pues según las abreviaturas que figuran en el índice de textos (p. 671), esta cita está tomada de la obra Expositio evangelii secundum Lucam, y debería haber aparecido con la abreviatura "Lu"; al aparecer la abreviatura "Lc", remitía a la consulta directa del evangelio de Lucas, lo que induce aún más a confusión sobre que el segundo miembro de la afirmación es un dato constrastado de la fe, si se supone, sin consultar, que aparece en el evangelio de Lucas. 
prácticas defectuosas y abusivas. Presentar a la Iglesia como un dechado de perfecciones es ir contra la verdad. Por otra parte, esta sugerencia se contradice abiertamente con lo que se afirma en el n. 825, que citando al concilio reconoce la santidad todavía imperfecta de la Iglesia. Sin embargo, una muestra de que la mentalidad de que la Iglesia constituye un reducto de salvación no está tan ajena al Catecismo es el n. 1.186. En un apartado aparentemente intrascendente, ya que está hablando de las diversas partes o espacio del templo se leen unas afirmaciones inverosímiles: "Para entrar en la casa de Dios ordinariamente se franquea un umbral, símbolo del paso desde el mundo herido por el pecado al mundo de la vida nueva al que todos los hombres son llamados". La Iglesia es la tabla de salvación, el refugio perfecto, la agrupación de los salvados; fuera de ella, el mundo va a la deriva, y el pecado y el mal imperan a sus anchas ${ }^{43}$. Decididamente, no. ¿Para dónde dejar el que "la Iglesia encierra en su propio seno a pecadores, siendo al mismo tiempo santa y necesitada de purificación" (LG 8)? ¿Por qué no acudir al clásico adagio de la "casta meretrix", tan repetido en la patrística?

El tema de la infalibilidad, a mi modo de ver, está mal presentado. Alude, sí, pero muy discretamente a la infalibilidad de la Iglesia (en el n. 889), aunque se centra mucho más directa y ampliamente en la infalibilidad papal, que viene en la presentación a dejar relegada la infalibilidad eclesial a un segundo plano. Se produce una alteración de los términos, y una manipulación del sentido de los términos conciliares, en detrimento de la primera afirmación, para exaltar la segunda. Debiera haberse dicho con toda claridad, además, cuáles son las condiciones en las que el Papa ha de ejercer la facultad de la formulación infalible, pero esas condiciones no aparecen en el Catecismo.

Con motivo de los laicos y sus funciones, lo cierto es que la corresponsabilidad está expresada de la peor manera posible cuando se afirma que "los laicos que sean capaces de ello y que se formen para ello también pueden prestar su colaboración en la formación catequética...". Ese "también" resulta poco menos que ofensivo, como si se trata de una concesión graciosa, olvidando que la raiz de la responsabilidad en la Iglesia arranca del bautismo.

La cuestión de la resurrección de los seres humanos está planteada en dos tiempos. En el primero de ellos se habla de la resurrección de los justos para siempre (n. 989 y 994); sólo más adelante se completa en un segundo momento en que se habla de la resurrección para castigo (n. 998 y 1.003). Yo

43 Cuando se llega a la cuestión de si hay salvación más allá de los límites de la Iglesia, en el n. 846 se afirma positivamente que la Iglesia es instrumento de salvación; y en el n. 847, citando a LG 16, se muestra que para los que son sinceros con sus creencias, al margen de la Iglesia que desconocen sin culpa suya, hay otros mecanismos de salvación. Resulta de este modo que todo lo que hay más allá de la Iglesia no es forzosamente malo y pecaminoso. 
creo que esta duplicidad no es válida, habida cuenta que el evangelio es mucho más directo y habla de ambas a la par (Jn 5, 29; Mt 25, 31-46).

A cuenta de la resurrección, se tiene el acierto de ser claros al rechazar explícitamente la reencarnación (n. 1013). El fallo que percibo en este punto es que hubiera sido más explícito y más honesto señalar que esta idea procede de la religión hindú, y que en consecuencia no es cristiana.

En la introducción a los sacramentos en general, el n. 1.125 señala la cautela de que los ritos no pueden ser caprichosamente alterados al arbitrio del celebrante o de la comunidad. Aunque el principio es totalmente válido, y tiene una mayor vigencia y fuerza prescriptiva en la Iglesia oriental, hay, sin embargo, algo de confuso en la formulación, puesto que al no hacer ningún otro tipo de advertencias, parece que lo que se fomenta es el puro ritualismo. Y no se dice una palabra del otro principio de adaptación y de las amplias posibilidades de elección que la liturgia aconseja para no caer en la monotonía o en la rutina.

No puedo decir que esté mal el n. 1.128. Pero no me queda más remedio que afirmar que está gravemente incompleto. La acción salvadora de Dios en los sacramentos (ex opere operato) no sólo no empaña sino que reclama la participación y aceptación del hombre (ex opere operantis), sin la cual tampoco hay salvación. Y mientras el primer punto sí figura en el número señalado, el punto segundo no aparece por parte alguna. Esto no es serio.

El tema de las imágenes empleadas en los templos lleva a una serie de consideraciones bastante amplias (n. 1.159-1.162) en el curso de las cuales no se menciona el $\mathrm{n}$. 125 de la Constitución de Liturgia que breve y acertadamente da unas normas al respecto.

Las explicaciones que se hacen sobre el tiempo en la liturgia (no sobre los tiempos litúrgicos), derivan hacia un sentido alegórico con matizaciones sutiles entre el "hoy" y la "hora", el "día primero" y el "octavo día" (n. 1.165-1.166) que en realidad siembran más obscuridad que claridad.

La referencia al bautismo de Juan, como precedente del bautismo establecido por Jesús, resulta válida; pero no queda muy clara cuál es la diferencia entre uno y otro bautismo (n. 1.223-1.224).

También en el tema del bautismo se hace una extraña pirueta en el n. 1.260 , porque, sin hablar expresamente de "cristianismo anónimo", se utiliza una expresión casi equivalente, al decir que en aquellas personas que desconocen la Iglesia "se puede suponer que habrían deseado explícitamente el Bautismo si hubiesen conocido su necesidad". ¿Qué sentido tienen andar haciendo semejantes suposiciones y equilibrios en la cuerda floja? ¿No es mucho más sensato, más veraz, y más ajustado a la doctrina del Vaticano II, ya citada, la frase anterior del mismo número: "Todo hombre que ignorando 
el Evangelio de Cristo y su Iglesia, busca la verdad y hace la voluntad de Dios según él la conoce, puede ser salvado"?

Y prosiguiendo el mismo tema, la cuestión de los niños muertos sin bautismo, resulta tibiamente tratada, pues por un lado acude al magnífico texto de $1 \mathrm{Tm}$ 2,4 "Dios quiere que todos los hombres se salven"; pero, por otro lado, no es capaz de extraer la consecuencia de que si los niños no tienen capacidad de oponerse personalmente a Dios, el deseo salvífico de Dios se impone con una rotundidad palmaria. En lugar de eso, la redacción del número en cuestión se diluye, porque a principio del número afirma que "la Iglesia puede confiarlos..." (tercer persona del singular) y después, cambia de persona y de número, y habla en un extrañísimo plural "nos permite confiar que haya un camino de salvación para los niños que mueren sin Bautismo". Parece que hay miedo a hacer afirmaciones claras, para que de esta forma no disminuya el número de bautismos.

Pasando a la cuestión de la eucaristía, se afirma en el n. 1.369 que "el obispo del lugar es siempre responsable de la Eucaristía, incluso cuando es presidida por un presbítero". Nada tengo que reprochar a ello. Simplemente pedir que se verifique, puesto que en ocasiones hay que participar en algunas eucaristías, que da la impresión de que los obispos son unos irresponsables. Lo más destacable no está tanto ahí, cuanto que se aduce un texto de Ignacio de Antioquía, que evidentemente está fuera de su contexto. Cuando Ignacio de Antioquía lo escribe, exhorta a la unidad en torno al obispo propio, que es signo visible de unidad frente al peligro inminente y actual de escisión. Cuando no se dan esas circunstancias, ni siquiera se hace cuestión de la legitimidad o no legitimidad de la celebración eucarística. Y ésta es la situación de la mayor parte de las ocasiones: sería bueno decirlo.

La fundamentación bíblica de la penitencia resulta gravemente empobrecida. No porque no se acuda a una serie de textos bíblicos, sino porque uno de los más explícitos y fundamentales, el de Jn 20, 21-23 resulta deficientemente empleado. Se alude a él como referencia en el n. 1.441; no se vuelve a citar ni emplear a lo largo de toda la parte expositiva y luego, en el resumen (n. 1.485) es cuando aparece íntegramente reproducido. ¿No hubiera sido más válido emplearlo antes?

No se me alcanza a comprender la razón del trato brevísimo con que se ha despachado el sacramento de la unción de enfermos (n. 1.519), ya que si para el bautismo o la confirmación se ha extendido el Catecismo con amplitud no encuentro motivos válidos para no hacer lo mismo con la unción de enfermos.

También sospecho a propósito de la unción de enfermos que estamos ante una defectuosa traducción castellana de la redacción original francesa, 
porque no de otro modo me explico la frase de que "el sacramento de la unción de los enfermos es concedido..." (n. 1.523). Los sacramentos no son concedidos, sino que son celebrados para aquellos que reúnen los requisitos necesarios, pero no son resultado de una concesión graciosa.

En el n. 1.537, sobre el orden sacerdotal, no se pone la palabra "epíclesis" que ha desfilado machaconamente en todos los sacramentos. Pero tampoco se reproducen las palabras esenciales de la oración consecratoria, ya que reproducirla íntegra resultaría demasiado prolongado. Se omite esto, que parece importante, y en cambio se reproduce una parte de ella para hablar de la conexión con el sacerdocio de Aarón (n. 1.541-1.543), lo que resulta bastante más secundario. En otros sacramentos se precisa cuál es la fórmula sacramental, y aquí no, sin justificación aparente.

En los n. 1.606-1.608 se produce una extraña situación, al hablar, en conjunto de "el matrimonio bajo la esclavitud del pecado". ¿Por qué hay que ceñirse al matrimonio, y no a otras facetas de la vida humana (relaciones laborales, trabajo, descanso, aspiraciones a la libertad,...) también bajo la esclavitud del pecado? No creo que salga beneficiado el matrimonio en esta consideración que pretende un recorrido para llegar a hablar del sacramento, pero que entraña unos acentos en torno al matrimonio que parecen incriminarlo: concupiscencia, egoísmo, agravios recíprocos, dolores de parto, ganarse el pan. De nuevo vuelve a aparecer que el problema estriba en tomar al pie de la letra las frase del Génesis a las que se alude.

Sobre el tema de las virtudes, el n. 1.804 se centra en el desarrollo de las virtudes humanas, lo que responde al título que le precede. Desde este número a los que le siguen inmediatamente, se produce un salto en el vacío, que no resulta explicado, pues se pasa de las virtudes "humanas" a las virtudes "cristianas", ya que el desarrollo de las tradicionalmente llamadas "virtudes cardinales" tiene unas connotaciones tan evidentemente cristianas que no se puede convenir en que sean tratadas como exclusivamente humanas.

Encuentro muy flojo el número 1.821, ya que al hablar de la esperanza, ésta tiene unos tintes espirituales de salvación ultramundana que desvirtúan toda labor apasionada de mejorar y transformar el mundo presente como colaboración del hombre con Dios creador. Esta aparecía más claramente en el n. 1.047, pero en esta ocasión queda fuera del horizonte de este número. Es cierto que la salvación no ha de quedar sólo en transformación intramundana, pero lo que resulta indiscutible es que el n. 1.047 resulta mucho más enriquecedor.

El Catecismo (n. 1.831) no mejora respecto a otros textos anteriores en cuanto a atenerse al texto bíblico de Is. 11, 2 en el cual figuran únicamente seis dones del Espíritu: “"Se posará sobre él el espíritu de Yahvéh: espíritu 
de sabiduría e inteligencia, espíritu de consejo y fortaleza, espíritu de ciencia y temor de Yahvéh". Tradicionalmente se ha forzado el texto desde tiempos muy remotos, para sacar también un septenario que catequéticamente se pudiera añadir a la lista de los ya existentes, y se añadió al texto de Isaías el "espíritu de piedad", que originalmente no figura en la Biblia.

En la clasificación que hace de los pecados, en los n. 1.854 y ss, el Catecismo los divide y clasifica en mortal y venial. Catequéticamente es mucho más válida una triple clasificación que diferencia entre mortal, grave o leve, pero el texto no la utiliza, con lo cual se desaprovecha una oportunidad ${ }^{44}$.

En ese mismo apartado de la clasificación de los pecados, a propósito del pecado mortal (n. 1.855), el Catecismo elude intencionadamente pronunciarse sobre algo que constituye un logro perfectamente consolidado en la teología moral, cual es la opción fundamental. Esto no se debe a un simple olvido. El deseo de acudir a la doctrina segura, ha llevado a los redactores al rechazo de una corriente en teología moral suficientemente contrastada, pero que no reviste la característica de doctrina tradicional. Y tan fe cristiana es la formulada en el pasado, como la elaborada en el presente, siempre que sea fiel a los dictados del evangelio.

$\mathrm{El}$ n. 1.865 tiene una redacción que no me convence. Es cierto que se ha empleado en multitud de ocasiones un estilo semejante, en el que el sujeto de la frase es "el pecado" y no "el pecador". Sin embargo, la redacción aquí presentada tiende a darle una especie de vida propia, autónoma, al pecado como si éste existiera con independencia de las decisiones que toma la persona pecadora. $Y$ "así el pecado tiende a reproducirse y a reforzarse, pero no puede destruir el sentido moral hasta su raiz". Creo que hubiera ganado mucho más la redacción y el sentido, si el sujeto gramatical de las afirmaciones hubiera sido la persona que por haber pecado tiende a separarse más y más de Dios, si no pone remedio.

El texto bíblico de Rm. 11, 32 aparece como única ocasión en el Catecismo en el n. 1.870, con la calificación de "resumen". Del texto en cuestión no se ha explicado nada antes; y el resumen se limita a reproducirlo, sin ninguna otra aclaración. Me parece que haberlo explicado no hubiera estado de más, especialmente por la dificultad intrínseca de que el texto bíblico atribuye a Dios, como causa primera, la acción de situar a los hombres en una actitud de rebeldía: ello puede llevar a algunos a pensar que la responsabilidad consiguiente es de Dios, y no de los hombres, como sujetos pasivos de la acción.

44 En el n. 1.864 se habla de la "blasfemia contra el Espíritu Santo", el llamado pecado mortal, del que no cabe hablar de perdón mientras subsista la actitud de rechazo y enfrentamiento respecto de Dios. Es lástima que se tenga en cuenta el contenido, pero no se saque partido de las posibilidades catequéticas que éste ofrece. 
El n. 1.884 creo que encierra un notable desacierto en la redacción, así como en lo que implica de fondo. La primera afirmación, como punto de partida, me parece desafortunada, al decir que "Dios no ha querido retener para El solo el ejercicio de todos los poderes"; esto puede causar la sensación de que todo el fenómeno asociativo y toda la vida social del hombre es una especie de concesión graciosa de Dios hacia los hombres. Pero aún me parece más desafortunada la última frase, según la cual los que gobiernan "deben comportarse como ministros de la providencia divina". Esta afirmación implica la visión creyente, sin duda, pero supone (o, al menos, puede interpretarse) que los gobernantes lo son por participación divina. Con ello estamos muy cerca de la consabida frase de que una persona es "rey de ..., por la gracia de Dios”. Yo me pregunto: ¿Dónde está la visión de la autonomía de las realidades temporales y de la genuina secularización como independencia de lo sacral? Porque es claro que esto hay que aplicarlo tanto al terreno de las realidades científicas, como a otros más que integran la vida del hombre. Aquí había una oportunidad, que no se ha sabido explotar. En cambio, está mucho mejor expresado, con la apelación a un orden moral justo en el n. 1.899 .

Avanzando en el terreno de la reflexión moral, aparece en el n. 1.948 una afirmación desconcertante: "La solidaridad es una virtud eminentemente cristiana". ¿Y para dónde dejar tantos y tantos ejemplos de solidaridad humana, practicados tanto por creyentes como por no creyentes? Es notorio que un creyente no puede aislarse y ser insolidario. Pero monopolizar la solidaridad en beneficio del cristianismo no es proceder con rigor.

En el n. 1.959 del Catecismo se debería haber expresado que lo que se afirma es un deseo, pero no siempre es una realidad, cuando se asegura que la "ley natural...establece la base moral indispensable para la edificación de la comunidad de los hombres". Debería establecerla, pero por desgracia no siempre es así, y no son nada raros los casos en que la ley natural y la ley civil de tal o cual lugar o momento presentan serias divergencias.

A mi modo de ver, el tema del testimonio cristiano, abordado en los $\mathrm{n}$. 2.044-2046 resulta muy pobremente tratado, y las posibilidades tan ricas que ello ofrece se han desperdiciado.

Las páginas 455 y 456 de la edición castellana incluyen a tres columnas la redacción de los mandamientos, con arreglo al texto de Ex 20, Dt 5 y la formulación catequética usual. Después hay que ir al n. 2.066, donde se hace una brevísima alusión a que esto ha variado en el curso de la historia, pero no se da una convincente explicación que haga frente a las principales diferencias que se establecen en la comparación de las tres columnas. Parece deducirse que tal comparación y la explicación consiguiente tiene que hacer- 
la el lector por sí mismo. O cuando esto se lleva a cabo, por ejemplo, en el n. 2.129 sobre el sentido adecuado de la prohibición de realizar imágenes, los textos bíblicos a los que se refiere, están lo suficientemente distantes, como para estimar que se están centrando sobre un asunto concreto, pero que la cuestión de las diferencias existentes entre las diversas formulaciones, se ha quedado sin aclarar.

Me parece pobre hasta decir basta la explicación sobre el sentido cristiano del domingo (n. 2.175-2.176) como culminación del sábado judío. La revaluación del sentido del domingo (que está presente en los n. 1.166 y 1.167) debería haberse sabido aprovechar en este momento, en lugar de hacer pinitos para contraponer sábado (judío) con domingo (cristiano). Otro tanto hay que decir del n. 2.180, en el cual se insiste en el aspecto moral y canónico de la obligación de la asistencia y participación en la misa, pero no aparece para nada la palabra "convencimiento", que es por donde se debería haber empezado.

Resulta a todas luces patente que el texto bíblico de Ef 4,2 que se reproduce en el n. 2.219 del Catecismo está mal utilizado, porque el número correspondiente está haciendo referencia a los relaciones entre hermanos de sangre, en tanto que el texto de la carta a los Efesios se refiere a los cristianos en general, hijos del mismo Dios, y por tanto, hermanos en la fe. No se trata de una contraposición absoluta, pero parece mentira que no se haya encontrado otro texto en la Biblia para ilustrar el tema de las relaciones cristiana entre los hermanos en el seno de la misma familia.

En el n. 2.260 se está tratando la cuestión del respeto a la vida humana; para ello se acude a un texto de Gn 9, 5-6. No hubiera sido una mala ocasión para hacer el paso interpretativo entre el concepto "sangre" y el concepto "vida", sobre todo habida cuenta de las interpretaciones restrictivas de los Testigos de Jehová, por ejemplo.

Los dos textos bíblicos que aparecen citados en el n. 2.270 del Catecismo hacen referencia al hecho de que toda vida humana está en manos de Dios, con lo que de alguna manera conectan con la explicación anterior (ya indiqué antes que se trata de un mal uso de la Biblia cuando ésta no es asumida como fuente, sino como corroboración de lo presentado). Pero lo que es evidente es que ninguno de los dos textos se refiere al respeto que se debe a la vida humana engendrada pero no nacida aún.

Cuando se trata la cuestión del respeto a la integridad corporal se hace referencia a los abusos de cualquier índole que se cometen contra la vida humana ${ }^{45}$, especialmente los llevados a cabo por parte de la autoridad cons-

45 Respecto al terrorismo (n. 2.297), J.L. LARRABE, en "Vida Nueva", n 1.897, 30 de enero de 1993, 4 señala un defecto de redacción por carencia de dos comas, ya que la frase, 
tituida. Ahora bien, la redacción utilizada es desvaída, muy poco concreta, y con miedo a llamar a las cosas por su nombre: en una velada alusión, se quiere dirigir, sin emplear la palabra, a la "inquisición", para lo cual emplea este circunloquio: "En tiempos pasados, se recurrió de modo ordinario a prácticas crueles por parte de autoridades legítimas para mantener la ley y el orden, con frecuencia sin protesta de los pastores de la Iglesia, que incluso adoptaron, en sus propios tribunales las prescripciones del derecho romano sobre la tortura. Junto a estos hechos lamentables, la Iglesia ha enseñado siempre el deber de la clemencia y la misericordia...” (n. 2.298) ¿Por qué hay miedo a emplear las palabras exactas, precisas y habituales? ¿Por qué no reconocer que, con todas las justificadas razones de situar esta práctica en otra época, lo que procede es admitir el error, sin rodeos?

En estricta continuidad con lo enunciado en el párrafo anterior, me parece que no hubiera estado de más, al abordar la cuestión de la paz de Cristo, en el n. 2.305, una nota histórica que reconociera también los fallos de la Iglesia cuando ésta ha sido parte beligerante, o cuando ha fomentado la guerra. El que hoy opte decididamente por la paz, como también lo ha hecho en otras épocas, no puede hacer olvidar al buen católico las miserias de una Iglesia que se ha alineado como contendiente en numerosas ocasiones.

En el n. 2.301, con una timidez que raya en el ridículo, se afirma a propósito de la donación gratuita de órganos que el hecho "es legítimo y puede ser meritorio" ¿De verdad que no hay nada mejor que decir? Resulta penoso comprobar que algo tan importante y tan altruísta como ayudar en vida con una decisión sopesada, para que otras personas enfermas puedan recuperar su salud no merezca otra consideración mejor. Nótese, para más inri, que ni siquiera se afirma que lo es, sino que lo "puede ser"; y tampoco se precisa en qué consiste dicho mérito.

Tan lamentable como eso es, en el mismo número, el brevísimo enunciado sobre la cremación de cadáveres, que es reflejo de una conducta sospechosa de no ser muy aceptada, cuando se dice que "la Iglesia permite la incineración". ¿Por qué no se dice, en plano de de igualdad, que la Iglesia permite la inhumación, o que permite arrojar un cadáver al mar? ¿Qué recelos inconfesados se ocultan en esa permisión graciosa?

A pesar de la claridad que tiene el texto de GS 79, que aparece citado en el n. 2.308 del Catecismo, la teoría sobre la "guerra justa" está hoy

materialmente hablando, aparece así: "El terrorismo que amenaza, hiere y mata sin discriminación es gravemente contrario a la justicia y à la caridad", cuando en realidad, la frase debería ser: "El terrorismo, que amenaza, hiere y mata sin discriminación, es gravemente contrario a la justicia y a la caridad". 
ampliamente superada, dada la reflexión que se ha llevado a cabo en este punto concreto. Lo malo es que parece que, puesto que tal reflexión es reciente, no tiene aún el carácter de "doctrina tradicional y segura", digna de ser incorporada a las páginas del Catecismo. Con ello se ha perdido una magnífica oportunidad de asumir una corriente de opinión en un tema que tiene una inevitable repercusión mundial, y que no obedece a la simple opinión aislada de un par de moralistas despistados.

Sin embargo, algo se quiere decir sobre el tan controvertido tema de la guerra, y el n. 2.315 se hace eco de la cuestión de la carrera de armamentos. Lo que ocurre es que lo hace con una frase, a mi modo de ver, muy desafortunada, ya que dice al terminar el número que la acumulación de armamentos "aumenta el riesgo de contagio". Creo que no hubiera resultado demasiado laborioso encontrar otra expresión mejor y más exacta.

Ya tuve antes oportunidad de señalar que resulta curioso que tenga que ser la Iglesia la institución que levante la bandera a favor de la fecundidad matrimonial, frente a un planteamiento generalizado que separa el placer sexual de la generación, como si se tratara de cosas opuestas. Sin embargo, creo que se comete una inexactitud cuando aparece escrito en el n. 2.366 que "todo 'acto matrimonial debe quedar abierto a la transmisión de la vida". El hacerlo extensivo a "todo acto matrimonial", sin excepción, pone en tela de juicio el principio de paternidad responsable. Quizá debería haberse enunciado el principio, matizando, puesto que no siempre ni obligatoriamente el acto sexual matrimonial tiene que incluir esa intencionalidad.

En el mismo tema, el rechazo explícito de cualquier medio de control de natalidad que no sea estrictamente natural (n. 2.370), parece dejar sentado el principio de que lo natural es bueno y lo artificial es malo. Sin embargo, no hay más remedio que recordar las múltiples ocasiones en que el hombre interviene con su talento, sus medios, su técnica o sus conocimientos en numerosos procesos naturales, y esta intervención artificial no sólo es estimada como buena, sino que se inscribe en la lógica de la colaboración del hombre en la obra creadora de Dios. Hacer esta excepción en la intervención humana sobre la regulación de la natalidad, resulta difícilmente explicable.

Casi prolonga el mismo asunto el n. 2.377, que rehúsa la inseminación artificial homóloga. Lo hace por una doble razón: la de disociar el hecho generativo del acto sexual; y la del empleo de una técnica muy concreta. Las dos razones son perfectamente discutibles. No quiero decir que no tengan su parte de razón en la polémica sobre el complejo mundo de problemas que se derivan de la utilización de la técnica que se aplica a los procesos de la generación de la vida. Problemas jurídicos, morales, éticos, médicos, psicológicos... Pero si es verdad que existen unas cautelas que señalan los especialis- 
tas y que dicta el sentir común y la proyección de las consecuencias que se derivan de la técnica, de ahí no hay que llegar a la consecuencia de que todo sea necesariamente rechazable. La técnica puede emplearse contra el hombre, así como también puede ser puesta al servicio del mismo hombre.

Los n. 2.384 y 2.386 plantean un problema. No porque la doctrina eclesiástica sobre el divorcio deje dudas sobre la oposición que esta forma de proceder sienta contra la voluntad expresa de Jesús, manifestada en el evangelio. El problema proviene del hecho de que en el n. 2.386 se habla de la diversa situación del "cónyuge inocente" y del "cónyuge que ha provocado el divorcio". En este punto, una fuerte corriente de opinión en la Iglesia, mantenida en diversidad de lugares y durante mucho tiempo, ha tratado de entender y aplicar correctamente la célebre excepción que el mismo Jesús señala en el texto de Mt 19, 9 ("salvo el caso de fornicación"), argumentando que el cónyuge inocente podía contraer nuevo matrimonio válido. No se trata de que esta excepción deje un portillo abierto a la exigencia evangélica, como si se tratara de la trampa de la ley. Se trata, más bien, de comprobar la dificultad de una adecuada interpretación, y que la puesta en práctica de una solución ante una situación de divorcio planteado ante la autoridad civil, a la cual se refiere expresamente el n. 2.386, también obliga a la propia Iglesia a considerar de diversa manera a uno y otro cónyuge. No está de más recordar las llamadas a la comprensión contenidas en los n. 1.650 y 1.651 del Catecismo.

En el tema de la propiedad, el n. 2.403 se mueve entre dos polos que hay que saber conjugar: el derecho a la propiedad privada, y el destino universal de los bienes. Hubiera sido de agradecer que, sin miedos ni rodeos, se hubiera hablado de que la propiedad privada tiene unos "límites", aun cuando después, en la práctica, resulte difícil señalar cuáles son los límites que encuadran el derecho, precisamente por la función social de los bienes. La dificultad práctica subsistiría, pero se habría ganado en claridad expositiva al hablar de propiedad limitada.

Es rigurosamente exacto afirmar que las obras de misericordia se tratan en el Catecismo en el contexto de la justicia (n. 2.447). Pero también es verdad que podrían haberse presentado aún más claramente como una forma adicional de superar los límites de la justicia, yendo más allá del estricto cumplimiento del deber marcado, pero, como es lógico, sin omitirlo o eludirlo. En cambio, el haber empezado por afirmar que "son acciones caritativas mediante las cuales ayudamos a nuestro prójimo" puede muy fácilmente evocar en numerosas personas que es suficiente con una acción caritativa para sentirse satisfecho, aunque se hayan dejado de lado las elementales exigencias de justicia. El planteamiento poco preciso no lo resuelve la frase que afirma que la limosna hecha a los pobres "es también una práctica de justicia 
que agrada a Dios". Se necesitaría haber sido más claros en este punto, ya que en ocasiones las cosas necesitan ser afirmadas con claridad, y no sólo dadas por supuestas. También en este punto echo de menos algo de imaginación para haber enunciado, además de las obras de misericordia clásicas, otras de nuevo cuño, más acordes con el mundo contemporáneo, pero no menos eficaces en la ayuda del prójimo.

En la parte dedicada a la oración, no veo muy claro que la oración normativa, fundamental y clave para todo cristiano, como es la oración del padrenuestro, sea tratada después, y no antes de la oración del avemaría, o de otras formas de oración. De hecho, a pesar del empleo de la letra pequeña,y del distinto espacio dedicado a cada una, se produce un desplazamiento que debería haberse evitado cuidadosamente.

Pero además, a propósito de la oración en relación con María, se aprecian en el Catecismo unos cambios de acentos que no aparecen explicados con la suficiente claridad. Se pasa de hablar de la oración "de" María (n. 2.617), a la oración "con" María (n. 2.673), y a la oración "a" María (n. 2.675). Cualquier lector inteligente puede apreciar que no es lo mismo una cosa que otra. Además, en los dos primeros casos, en la oración de María como mujer creyente, y en la oración junto con María, hay menos problemas teológicos. Pero en el caso de la oración a María, el tema tiene que ser un poco más matizado: lo hace el n. 2.674, en que se afirma que Jesús es el único Mediador. A mi modo de ver, no se dice con suficiente claridad que María es intercesora ante Dios, y puede dar la sensación de que también ella queda incluída en la categoría de mediadora, entrando en conflicto con los datos bíblicos ( $\mathrm{Hb} \mathrm{8,} \mathrm{6;} \mathrm{1Tm} \mathrm{2,} \mathrm{5).} \mathrm{Dejar} \mathrm{estas} \mathrm{cosas} \mathrm{claras} \mathrm{favorece,} \mathrm{y} \mathrm{no} \mathrm{poco,} \mathrm{el}$ diálogo ecuménico.

No veo muy clara la alusión que hace el n. 2.687 a los anacoretas retirados a la oración en el desierto de Egipto, puesto que parecidas decisiones han sido adoptadas por otros cristianos en diversas épocas de la historia y en los lugares más variados, con idéntico deseo de dirigir sus vidas a Dios. ¿Por qué hay que convertir una determinada época en una especie de "edad de oro" idealizada? ¿Por qué no dar la misma importancia a otras situaciones?

Que la iglesia, es decir, el templo, sea lugar "favorable" para la oración, o que sea el "lugar propio" de la expresión litúrgica, me parece irreprochable (n. 2.691). Debería haberse dicho también que para un cristiano, que adora "en espíritu y en verdad", cualquier lugar es bueno, puesto que es lugar de encuentro con Dios, y fruto de sus manos creadoras; se daría por superada la antigua polémica de "si en este lugar o en Jerusalén". Y por supuesto, no se hubiera devaluado el puesto o la utilidad que el templo reporta. 
Son bastante numerosos los aspectos que encuentro defectuosos en el Catecismo, y que me parece que reclaman unas precisiones y en algunos casos unas rectificaciones que tendrían que ser, actualmente, innecesarias. Si es verdad, como se dice en el Dossier informativo, que han funcionado y existido tanto filtros, cribas y análisis en las sucesivas redacciones ${ }^{46}$, parece mentira que hayan sido tantas cosas las que se han deslizado a los ojos de los redactores y traductores. Es verdad que en ellas van implicados puntos de vista diversos; pero no es menos cierto que en muchas ocasiones un simple giro en la frase, la introducción de una palabra, o la supresión de otra hubieran determinado un acierto mayor. Si me he fijado en los aciertos tanto como en los fallos es porque encuentro ambas cosas. Y presentar solamente una parte de la realidad, ocultando la otra no sería válido. Me hubiera gustado poder decir que los defectos eran mínimos, pero se puede apreciar que la lista es notable. Es decir, que como toda obra humana, adolece de fallos que deberían haberse examinado más cuidadosamente.

Quiero, a este respecto añadir una consideración más, que me parece que no tiene nada de irrelevante. Si mis informaciones no son erróneas, parece que el haber redactado el texto del Catecismo en primer lugar en una lengua moderna (en el caso presente, en francés) hacía posible y más fácil llevar a cabo la traducción a las otras lenguas modernas más usuales. Se relegaba para un segundo momento la traducción latina, por la dificultad añadida de verter conceptos desde lenguas vivas a una lengua muerta, de uso intraeclesial. Pero me han llegado informaciones de que además hay otra razón suplementaria en el desfase hasta la publicación de la versión latina. Esta consiste en esperar a ver cuál es la reacción producida ante las diversas versiones (en este momento la versión inglesa sufre también un retraso considerable). Y una vez apreciadas esas reacciones (léase fallos, defectos de traducción, de redacción, de citas, etc) proceder a llevar a cabo la versión latina corregida, que es la que sería considerada texto oficial. Hacer el texto oficial después de ver los fallos producidos, no me parece el procedimiento mejor. Si en dicho texto se subsanan todos o algunos de los defectos, algo habremos conseguido. Pero de esta forma, el uso exclusivo de la versión castellana, en nuestro caso, nos deja desarbolados. En cualquier caso las páginas precedentes pueden poner sobre aviso a los lectores para detectar algunos de los defectos que el Catecismo presenta.

46 Dossier informativo, 19: fechas de los diversos proyectos, que abarcan desde febrero de 1987, con un primer borrador, hasta el proyecto definitivo (14 de febrero de 1992), y su redacción y aprobación respectivamente el 30 de abril y el 25 de junio del mismo año. A ello hay que añadir la traducción a la correspondiente lengua. 


\section{Dudas sobre la oportunidad.}

Junto a todo lo anterior, hay algunas otras cuestiones que a lo largo de las páginas de la obra comentada me plantean serias dudas sobre la oportunidad de su presencia. Esta oportunidad no se refiere a si deben ser tratadas en este o aquel lugar concreto, sino sobre si deben ser tratadas en un Catecismo que pretende presentar lo fundamental de la fe cristiana. Es claro que en algunos casos, el abordar una cuestión lleva aparejado el que aparezca otra de índole secundaria que guarda una cierta relación. Pero ahí es precisamente donde sitúo estas preguntas sobre la oportunidad, puesto que ninguno de los enunciados que vienen a continuación se centra en algún aspecto o contenido notable de la fe, y puedo asegurar sin temor a equivocarme que todos ellos podrían haberse suprimido perfectamente, sin que el contenido de la fe cristiana se hubiera resentido.

A la vista de ello, parece que hay que llegar a la conclusión de que lo que ha presidido gran parte de los trabajos preparatorios ha sido una preocupación de incluir absolutamente todo lo que tenía relación con la fe cristiana, tanto principal como accesorio. Y con ello se ha incumplido la petición del sínodo de 1985 que pedía "un catecismo o compendio de toda la doctrina católica en lo que se refiere tanto a la fe como a la moral". Si se trata todo compendiado, hay muchas cuestiones que podrían haber quedado fuera, porque nada fundamental se ventila en ello. Y no se ha hecho así.

El primer ejemplo de esto lo encuentro en el n. 108 que afirma que la religión cristiana no es una "religión del Libro". Cualquier conocedor de la historia de las religiones sabe que semejante frase se aplica sin género de dudas al judaísmo. Nada se hubiera perdido si no se hubiera incluído esta afirmación para pasar a afirmar que el cristianismo se nutre de la Palabra de Dios que es Jesús.

Los n. 116-118, a propósito del sentido literal, espiritual, alegórico, moral y anagógico de la Biblia, así como el dístico medieval que los resume, son otro ejemplo de lo dicho. De haberlo suprimido, para nada habría sufrido menoscabo la calidad de la enseñanza ofrecida.

La afirmación de que el credo está articulado en doce afirmaciones, que acostumbra a simbolizar el número de los Apóstoles (n. 191), es una afirmación trasnochada a estas alturas. Es cierto que no se afirma que los apóstoles lo redactaron, ni se llega, como se hizo durante mucho tiempo, a asignar la paternidad de cada frase al apóstol correspondiente. Pero es que ni siquiera resulta importante articular la fe cristiana en doce o en cincuenta afirmaciones, con tal de que lo que se presente sea genuinamente la fe cristiana. 
La afirmación de los ángeles custodios no tiene un carácter dogmático definitivo en la Iglesia. Los textos bíblicos que el Catecismo aduce para resaltar su importancia (n. 336), salvo los dos primeros, pertenecen al Antiguo Testamento y reflejan una mentalidad determinada, de unos mediadores entre Dios y los hombres; es evidente que los dos textos neotestamentarios (en contextos muy diversos) tampoco van a resolver la cuestión, afirmada más por la piedad cristiana que por los datos de la revelación. No creo que se hubiera comprometido seriamente el dogma de haber procedido a la supresión de este número.

Ya indiqué la falta de oportunidad que conlleva hablar del "Corazón de Jesús" (n. 478), aunque se le quiera dar un giro a la situación para hablar de que se pretende acentuar el sentido bíblico, según el cual, el corazón entraña lo más profundo del ser (n. 368). Porque, de ser coherentes, en el caso de querer recurrir a la Biblia, habría que hablar igualmente de los riñones, ya que son numerosos los pasajes del Antiguo Testamento que los identifican como la base de los sentimientos más profundos. Hubiera sido más que suficiente con limitarse a hablar del amor de Jesús hacia los hombres, dejando a un lado cada víscera en particular.

Entiendo que es de una irrelevancia absoluta (además de su escasa claridad) hablar de que "la dimensión mariana de la Iglesia precede a su dimensión petrina" (n. 773), para indicar el papel importante de María en el conjunto de los creyentes que forman la Iglesia ${ }^{47}$. Es más que seguro que nada fundamental de la fe cristiana está implicado en esta afirmación.

Que el carácter personal de toda misión entraña una responsabilidad, es un hecho notorio. Si se afirma a propósito del ministerio episcopal (n. 878), habría que hacer lo propia a cuenta de todos y cada uno de los quehaceres y ministerios en la Iglesia. No veo, en consecuencia, la oportunidad de hacerlo en este caso y no en otros. Si además se hace de una manera tan confusa y vidriosa, como tuve ocasión de mostrar, se refuerza la impresión de que hubiera sido mejor suprimir este número sin grandes problemas.

Ya dije que, con todo respeto hacia los ermitaños (n. 920-921), su situación me parece de menor entidad eclesial, y de menos conflictividad que la de los sacerdotes secularizados o los cristianos divorciados. ¿Se pretendía presentar con relación a la Iglesia todos y cada uno de los carismas y ministerios? No entiendo la necesidad de una enumeración exhaustiva, para hablar

47 Además, en esta cita expresa, se pone como referencia para localizarla "(ibíd.)"; esto lleva a suponer que hay que encontrarla en la cita inmediatamente anterior, que es precisamente de la carta a los Efesios, 5, 27. En dicho lugar no se encuentra este texto, puesto que la cita remite a la abreviatura que se ha utilizado más arriba, y que corresponde a Mulieris Dignitatem, 27. 
en definitiva de la diversidad de situaciones en las que un cristiano puede seguir a Jesús.

En el n. 1.000 se encuentra un ejemplo de escasa o nula oportunidad. Para decir que ignoramos cómo se ha de producir la resurreción de los muertos, es suficiente con decirlo en una simple línea. ¿Hay necesidad de acompañarlo con una cita de San Ireneo que tampoco aclara nada? ¿No es mucho más fácil tender a la sencillez que buscar la complicación para venir a decir lo mismo?

Me parece que el n. 1.034 sobre las afirmaciones de Jesús sobre el infierno, sin negar para nada los datos de la fe, se podría haber resuelto con la idea de que Jesús utiliza un lenguaje metafórico, que, por lo mismo, no debe ser tomado al pie de la letra, pero que remite a una realidad de castigo para los que han incumplido la voluntad de Dios.

Tampoco entiendo que haya que gastar energías y esfuerzos en hablar precisamente de lo que no se conoce. Es el caso de la afirmación que aparece en el n. 1.115 sobre "las palabras y las acciones de Jesús durante su vida oculta". Si no sabemos nada de ello, ¿para qué hacer literatura? Con aceptar lo que los evangelios nos han transmitido para llegar a conocer quién era Jesús de Nazaret, hay más que suficiente. Lo otro es perder el tiempo.

El n. 1.170 hace el Catecismo un inciso para detenerse en aclarar la diversa fecha de la celebración de la pascua en la disciplina oriental y occidental. Es claro que ello no comporta nada básico. Si se entretiene en esto, ¿por qué no hacer lo propio con otras muchas diferencias entre ambas disciplinas (fecha de la navidad, forma de hacer la señal de la cruz, importancia del incienso o las velas, o la disposición material del templo...)?

Hablar de los diversos nombres de la eucaristía ocupa en el Catecismo los números 1.328-1.332 (algo más de una página); de verdad estoy convencido que esto podría haberse resumido, puesto que no se trata de profundizar en un aspecto concreto, ni tampoco hacer un tratado de historia de la liturgia.

La afirmación que viene a continuación me parece poco menos que burlesca. No resulta ni serio ni digno que después de haber tratado del sacramento del matrimonio se dediquen unas líneas a las personas que permanecen solteras, por la razón que sea, y queriendo ensalzar su situación para que no se sientan preteridas se afirme que "estas personas se encuentran particularmente cercanas al corazón de Jesús” (n. 1.658) ¿A qué viene este reparto de entradas, con asientos de preferencia y de general? ¿Y qué razón hay para privilegiar una situación respecto a otra? Desde luego esto no es un modo muy adecuado de decir algo válido sobre los solteros. La solicitud eclesial a la que apela resulta bastante más notable que estas sugerencias de motivos "espirituales" de tan dudosa consistencia. 
Estimo oportuno decir una palabra sobre las exequias cristianas (n. 1.680-1.683). Explicitar el desarrollo de las mismas en un Catecismo (n. 1.684-1.690) podría haberse suprimido o condensado en gran medida. Ya he indicado que un Catecismo no es un manual de liturgia.

Un "tratado" clásico en los catecismos ha sido el de los dones y frutos del Espíritu Santo. Constituían una doble enumeración que había que saber, pero que resultaba desconectada del conjunto articulado de la fe y la moral, como un apéndice. En el presente Catecismo no se ha conseguido una mejor integración: aparecen colocados a continuación de las virtudes en un injerto forzado, en el discurrir de la moral fundamental (n. 1830-1.832). Después, en la exposición de la moral correspondiente a cada uno de los mandamientos, estos dones y frutos aparecen como no operativos para prácticamente nada. ¿No se podría haber buscado un entronque mejor? Y si no lo hay, ¿no se podrían haber suprimido del Catecismo?

Me parece que el número 2.158 podría haber desaparecido sin que el conjunto de la obra sufriera merma notable. De ese número la primera y más notable afirmación se podría haber trasladado al hablar de la vocación a la vida cristiana. El respeto debido a una persona, como el respeto a su fama, a sus bienes, a su dignidad o a su imagen ya ha sido abordado en otros lugares, sin necesidad de otros matices.

Habría aún más pasajes que señalar, bastantes más números que se limitan a repetir lo anteriormente enunciado, o que descienden a explicaciones difíciles, o a matizaciones escasamente necesarias. No es cuestión de prolongar la lista: Pero cualquier lector inteligente del Catecismo puede hacerse la misma pregunta por la oportunidad o inoportunidad de que figuren entre sus páginas ciertas explicaciones que podrían haberse suprimido sin mutilar nada fundamental ni importante de la fe. Esto lleva a una inevitable conclusión. Podría haberse hecho un catecismo más sencillo, pero no menos fundamental. El afán de no dejar nada por decir ha llevado a que la criatura haya nacido demasiado gorda.

\section{Balance final.}

Ya va siendo hora de poner fin a este tan dilatado trabajo. Pese a los muchos puntos comentados, quedan otros, que podrían ser analizados en bloque o por separado. Ya ha habido quien ha realizado algunos estudios por partes, centrando su atención en la especialidad correspondiente: aspectos bíblicos, textos patrísticos, tratamiento dado a la moral, datos teológicos implicados, problemas específicamente catequéticos,... El análisis podría prolongarse. Pero no procede pretender agotar la materia. 
En cuanto constituye este estudio han ido desfilando una serie nada despreciable de aciertos y fallos, de visiones o enfoques con los que legítimamente se puede disentir, de pautas catequéticas fundamentales sistemáticamente eludidas. También han aparecido criterios según los cuales no debería hacerse ningún tipo de crítica a un Catecismo que se publica con los parabienes oficiales, a fin de no mermar su credibilidad. Como si la credibilidad o el prestigio vinieran tan sólo de la ausencia de críticas (más aún, si tal ausencia ha sido previamente ensayada y acordada).

Si he sido crítico es porque se trata de un legítimo sentido de discernimiento que me siento obligado a hacer para que otras personas, otros creyentes, puedan formar responsablemente su propio juicio con conocimiento de causa, en el ejercicio de una sana libertad.

Hay algunos aspectos que no quisiera dejar de decir. Uno de ellos, importantísimo, cual es de la afirmación de la jerarquía de verdades. El Catecismo cita este pasaje en el n. 90 . El contexto conciliar afirma que en el diálogo ecuménico, a la hora de exponer y comparar la fe católica con la de otros grupos cristianos es preciso tener en cuenta la íntima vinculación interna que vincula a unas afirmaciones de fe con otras, proporcionándolas una estructuración en torno a lo fundamental de la fe. Esta afirmación, contenida en el decreto sobre el ecumenismo (Unitatis redintegratio, 11) es, en frase de Oscar Cullmann, "el pasaje más revolucionario no sólo del esquema De Oecumenismo, sino de todos los esquemas del Concilio". Y algo tan notable ha de ser tenido en cuenta tanto al presentar la fe católica para contrastarla con otros grupos cristianos, como al ofrecerla a los propios católicos. Sin embargo, aunque el Dossier informativo declare la voluntad que ha presidido a los redactores para seguir este principio básico ${ }^{48}$, lo cierto es que no lo han conseguido.

Son tal cantidad de afirmaciones, tan diversas en cuanto a la verdad que encierran, tan diversamente conectadas con lo nuclear de la fe, que el bosque de aseveraciones no deja percibir con claridad lo esencial, diferenciándolo de lo secundario. Ya he indicado que el empleo de dos tipos de letras (tres, si se incluye además lo relativo a los resúmenes) no contribuye a aclarar las cosas. Lo cierto y seguro es equiparado en ocasiones a lo meramente opinable. La proporción debida no siempre se ha sabido mantener. Algunos temas no aparecen suficientemente trabados. Se han querido de decir muchas cosas, demasiadas, y ello ha ido en perjuicio de la claridad expositi-

48 Dossier informativo, 24. Resulta significativo en este punto que empiece refiriéndose a este criterio de la "jerarquía de verdades" con la afirmación de que "no es una expresión del todo adecuada", como si hubiera una larvada intención de rectificar o corregir el documento del Vaticano II. 
va. En cambio, ha habido otras cuestiones destacables que no han encontrado hueco (o apenas un resquicio) en las páginas del Catecismo: por ejemplo, la corresponsabilidad eclesial, la secularización, la humildad del reconocimiento de los propios errores, el diálogo con el ateísmo,...

Creo, en definitiva, que el Catecismo es un instrumento (Fidei depositum, 4) a utilizar entre otros posibles, pero ciertamente no el mejor, ni tampoco el peor; creo que es un servicio (Fidei depositum, 4; también, n. 1.075) que puede reportar alguna utilidad. Sin necesidad de echar las campanas al vuelo, conscientes de las limitaciones y los logros que comporta, los dispuestos a hacer un esfuerzo de lectura y estudio, pueden utilizarlo como una orientación, entre otras, para conocer y exponer la fe.

LUIS RESINES

Valladolid 